\title{
Orexin Receptor Multimerization versus Functional Interactions: Neuropharmacological Implications for Opioid and Cannabinoid Signalling and Pharmacogenetics
}

\author{
Miles D. Thompson ${ }^{1, *}$, Takeshi Sakurai ${ }^{2}$, Innocenzo Rainero ${ }^{3}$, Mary C. Maj ${ }^{4}$ and \\ Jyrki P. Kukkonen ${ }^{5,6}$ \\ 1 Department of Pediatrics, University of California, San Diego, CA 92093, USA \\ 2 Department of Molecular Neuroscience and Integrative Physiology, Faculty of Medicine, \\ Kanazawa University, Kanazawa 920-8620, Japan; tsakurai@med.kanazawa-u.ac.jp \\ 3 Department of Neuroscience, University of Turin, 10124 Torino, Italy; innocenzo.rainero@unito.it \\ 4 Department of Biochemistry, School of Medicine, Saint George's University, Saint George's 11739, Grenada; \\ mary.c.maj@gmail.com \\ 5 Biochemistry and Cell Biology, Department of Veterinary Biosciences, University of Helsinki, 11739 Helsinki, \\ Finland; jyrki.kukkonen@helsinki.fi \\ 6 Department of Physiology, Institute of Biomedicine, Biomedicum Helsinki, University of Helsinki, 00100 \\ Helsinki, Finland \\ * Correspondence: mithompson@ucsd.edu
}

Received: 28 August 2017; Accepted: 29 September 2017; Published: 8 October 2017

\begin{abstract}
Orexins/hypocretins are neuropeptides formed by proteolytic cleavage of a precursor peptide, which are produced by neurons found in the lateral hypothalamus. The G protein-coupled receptors (GPCRs) for these ligands, the $\mathrm{OX}_{1}$ and $\mathrm{OX}_{2}$ orexin receptors, are more widely expressed throughout the central nervous system. The orexin/hypocretin system has been implicated in many pathways, and its dysregulation is under investigation in a number of diseases. Disorders in which orexinergic mechanisms are being investigated include narcolepsy, idiopathic sleep disorders, cluster headache and migraine. Human narcolepsy has been associated with orexin deficiency; however, it has only rarely been attributed to mutations in the gene encoding the precursor peptide. While gene variations within the canine $\mathrm{OX}_{2}$ gene hcrtr 2 have been directly linked with narcolepsy, the majority of human orexin receptor variants are weakly associated with diseases (the idiopathic sleep disorders, cluster headache and polydipsia-hyponatremia in schizophrenia) or are of potential pharmacogenetic significance. Evidence for functional interactions and/or heterodimerization between wild-type and variant orexin receptors and opioid and cannabinoid receptors is discussed in the context of its relevance to depression and epilepsy.
\end{abstract}

Keywords: orexin/hypocretin; $\mathrm{OX}_{1}$ orexin receptor; $\mathrm{OX}_{2}$ orexin receptor; homo-dimerization; hetero-dimerization; opioid receptor; $\mathrm{CB}_{1}$ cannabinoid receptor; status epilepticus; feeding behavior; sleep disorder

\section{Introduction}

The identification of a role for the orexins in narcolepsy contributed greatly to the field of orexin genetics [1], but later findings related to other physiological functions, including genetic determinants, also continue to propel this research [2]. The discovery of other functions of the orexinergic system provided fresh rationales for exploring orexin pharmacogenetics. Since the development of orexinergic drugs as sleep aids [3], it has become clear that there is a need for a greater understanding of the 
molecular pharmacology and pharmacogenomics of the orexins $[4,5]$ and those systems they interact with (eg. cannabinoid and opioid systems).

Orexin receptors belong to the rhodopsin family of the G protein-coupled receptor (GPCR) superfamily. They have been described as able to interact with several heterotrimeric $G$ protein subfamilies as well as other proteins: resulting in a range of cellular responses as a result of the action of ion channels, phospholipases and protein kinases. These signalling pathways control numerous events such neuronal excitation, synaptic plasticity, and cell death [6-8]. The specific signalling features in different cell types are likely determined by the expression profile of signalling components, signal complexes and concurrent signals.

An outline of the molecular biology of the orexins, therefore, is introduced prior to examining orexin pharmacology in the context of the functional interactions and/or di/oligomer formation that may take place with other receptors such as the cannabinoid $\mathrm{CB}_{1}$ receptor. While sequencing projects, such as the Exome Aggregation Consortium (http://exac.broadinstitute.org), have revealed that variants of the $\mathrm{OX}_{1}$ and $\mathrm{OX}_{2}$ receptors are common in the population (Tables 1 and 2) most have only been weakly associated with disease [2,5]. However, we acknowledge the possibility that co-expression of variant receptors could result in a distinct pharmacology through functional interaction or as a result of the formation of variant heterodimers. Our present focus, however, is to examine the evidence for whether an orexin receptor functional interaction or heteromerization with cannabinoid $\mathrm{CB}_{1}$ receptors contributes to some disease or pharmacogenetic phenotypes.

Table 1. $\mathrm{OX}_{1}$ orexin receptor variants investigated in disease. aa, amino acid; IC, intracellular loop; $\mathrm{SNP}$, single nucleotide polymorphism; TM, transmembrane helix [2].

\begin{tabular}{|c|c|c|c|c|c|c|c|}
\hline $\mathrm{OX}_{1}$ aa & Location & SNP & $\begin{array}{c}\text { Numbering/ } \\
\text { Peyron }\end{array}$ & $\begin{array}{l}\text { Numbering/ } \\
\text { 0lafsdottir }\end{array}$ & Frequency & Findings & Ref. \\
\hline 167 Gly/Ser & TM4 & rs44603792 & - & $652 \mathrm{G} / \mathrm{A}$ & 0002 & - & [9] \\
\hline $265 \mathrm{Leu} / \mathrm{Met}$ & IC3 & rs41501244 & $793 \mathrm{C} / \mathrm{A}$ & - & 0.001 & - & [10] \\
\hline $279 \mathrm{Arg} / \mathrm{Gln}$ & IC3 & rs7516785 & - & $989 \mathrm{G} / \mathrm{A}$ & 0.008 & - & [9] \\
\hline 280 Gly / Ala & IC3 & NP_001516 & 842 GIA & $995 \mathrm{G} / \mathrm{A}$ & 0.008 & - & {$[9,10]$} \\
\hline $\begin{array}{c}281 \mathrm{Arg} / \mathrm{His} \\
408 \mathrm{Ile} / \mathrm{Val}\end{array}$ & $\begin{array}{c}\text { IC3 } \\
\text { C-term }\end{array}$ & $\begin{array}{c}\text { rs41439244 } \\
\text { rs227 I933 }\end{array}$ & 1222 GIA & 1375 G/A & 0.56 & - & {$[9,10]$} \\
\hline- & - & - & - & - & - & $1.4 \mathrm{X}$ migraine & [11] \\
\hline- & - & - & - & - & - & $\begin{array}{l}1.6 \times \text { mood } \\
\text { disorders } \\
\text { Polydinsia- }\end{array}$ & [12] \\
\hline- & - & - & - & - & - & $\begin{array}{c}\text { hyponatremia } \\
\text { in schizophrenia }\end{array}$ & {$[13,14]$} \\
\hline- & - & - & - & - & - & Panic not linked & [15] \\
\hline
\end{tabular}

Table 2. $\mathrm{OX}_{2}$ orexin receptor variants investigated in disease. aa, amino acid; IC, intracellular loop; $\mathrm{SNP}$, single nucleotide polymorphism; TM, transmembrane helix; $\mathrm{CH}$, cluster headache [2].

\begin{tabular}{|c|c|c|c|c|c|c|c|}
\hline $\mathrm{OX}_{2}$ aa & Location & SNP & $\begin{array}{c}\text { Numbering/ } \\
\text { Peyron }\end{array}$ & $\begin{array}{l}\text { Numbering/ } \\
\text { Olafsdottir }\end{array}$ & Frequency & Findings & Ref. \\
\hline 10 Pro/Ser & N-term & rs41271310 & $28 \mathrm{C} / \mathrm{T}$ & 352 C/T 0.003 & 0.003 & Not linked & {$[5,9,10]$} \\
\hline- & - & - & - & - & - & with narcolepsy & - \\
\hline- & - & - & - & - & - & with narcolepsy & - \\
\hline 193 Cys/Ser & TM4 & rs41381449 & $577 \mathrm{~T} / \mathrm{A}$ & - & 0.002 & $-T^{-}$ & [10] \\
\hline 293 Ile/Val & IC3 & rs74720047 & & $1201 \mathrm{G} / \mathrm{A}$ & 0.002 & - & [9] \\
\hline- & - & - & - & - & - & $\begin{array}{c}\text { Migraine not } \\
\text { associated }\end{array}$ & [16] \\
\hline- & - & - & - & - & - & Some association & [17-19] \\
\hline- & - & - & - & - & - & with $\mathrm{CH}$ & - \\
\hline- & - & - & - & - & - & $\begin{array}{l}\text { No effect on triptan } \\
\text { response }\end{array}$ & {$[20]$} \\
\hline 401Thr/lle & C-term & rs41321149 & $1202 \mathrm{C} / \mathrm{T}$ & 0.00012 & - & - & [10] \\
\hline
\end{tabular}




\section{The Molecular Biology of the Orexins}

In 1998, two research teams, the groups of De Lecea/Sutcfliffe and Sakurai/Yanagisawa, independently published their discovery of novel neuropeptides which are exclusively expressed in a small group of neurons localized to the lateral hypothalamus [21,22]. Based on their location of origin and their sequence similarity to the gut hormone secretin, the De Lecea/Sutcfliffe group named these peptides the hypocretins [22]. As the lateral hypothalamus is classically implicated in the regulation of feeding, the Sakurai/Yanagisawa group assessed the role of this neuropeptide system in appetite regulation. The positive experimental results lead Sakurai/Yanagisawa group to name the peptides "orexins" after the Greek word for appetite [21]. Both groups in parallel identified the precursor peptide, preprohypocretin or preproorexin (PPO), which undergoes cleavage to form two smaller peptides, named hypocretin- 1 and -2 or orexin-A and -B, respectively. The gene which encodes PPO is located in human chromosome 17q21.2, and codes for a 131 amino acid peptide. The processed mature neuropeptides orexin-A/hypocretin- 1 and orexin-B/hypocretin-2 are 33 and 28 amino acids in length, respectively.

The initial focus of the De Lecea/Sutcliffe group was to identify mRNA transcripts selectively expressed in the hypothalamus [22]. Subsequent biological assays with the hypocretin-2/orexin-B peptide showed neuroexcitatory activity on cultured hypothalamic neurons. The work of the Sakurai/Yanagisawa group began with identifying peptide ligands for the putative orphan GPCR, HFGAN72 [21]. Using extracts of rat brain and a cell-based reporter system, the receptor was found to be activated by two peptides now known as orexin-A and -B. The orphan receptor found to have highest affinity for orexin-A was named the $\mathrm{OX}_{1}$ receptor. By making use of homology, an additional orexin receptor, $\mathrm{OX}_{2}$, was identified, and subsequently shown to have an equal affinity for both orexin peptides. PPO mRNA distribution in the central nervous system (CNS) was mapped. The peptides were found to be linked to the regulation of feeding behaviour based on evidence that they stimulated food intake upon intracerebroventricular (ICV) administration, and that PPO mRNA expression in the hypothalamus was increased upon fasting [21].

In addition to appetite, further studies established the role of the orexin/hypocretin system in sleep and wakefulness cycles, metabolic regulation, stress responses, reward/addiction and analgesia $[6,21,23]$. This complexity may reflect the widespread projections of orexin-producing neurons within the CNS. The physiological role for the action of the orexin/hypocretin ligands at the $\mathrm{OX}_{1}$ and $\mathrm{OX}_{2}$ receptors in the regulation of wakefulness and sleep is one example. Mignot and co-workers isolated two hcrtr2 gene (the gene encoding $\mathrm{OX}_{2}$ ) frame-shift mutations responsible for hereditary canine narcolepsy [24]. The frame-shifts both generate a premature stop codon. Truncated receptor proteins do not traffic to the plasma membrane and remain localized in the cytoplasm [25]. Work by Yanagisawa and co-workers concurrently showed that knockout of the precursor peptide, PPO, causes a narcoleptic phenotype in mice [26], which is stronger than the phenotype obtained upon $\mathrm{OX}_{2}$ knockout [27]. In 2000, a profound decrease in the concentration of orexin-A was reported in the cerebrospinal fluid (CSF) of human narcoleptics with cataplexy [28]. Only a few narcolepsy patients have been shown to harbor T47G (Leu16Arg; the signal peptide) and-C22T (a.k.a. C3250T; $5^{\prime}$ untranslated region) variants of PPO [1,10]. Studies of the Leu16Arg PPO mutant suggested that the processing and trafficking of the PPO are impaired [10], leading to subsequent problems with orexin peptide maturation and release. Although rare, the pathogenic orexin peptide variants identified in narcolepsy provided the rationale for the systematic study of orexin signalling in sleep disorders and with respect to individual differences in drug response.

Orexins play a role in numerous physiological processes including sleep-wake cycle regulation and the stimulation of feeding and regulation of energy homeostasis [29]. Additionally, exogenous orexins stimulate a number of processes in the periphery of the body, including gastric acid secretion [30] and glucocorticoid release [31,32], but the physiological significance of these is not known. Furthermore, in mice, orexins influence the regulation of feeding and metabolism, and their expression is altered by food deprivation $[33,34]$. Since there is very limited knowledge as to the effects of orexin peptide 
and receptor variants from heterologous expression systems, it is difficult to predict a role for these processes in human disease. However, mutagenesis studies, modeling and orexin receptor crystal structures have generated data upon which models of orexin receptor-ligand interaction may be predicted [35-41].

\section{Orexin Receptor Variants}

Genetic variants of the orexin system have been identified. While amino acid sequence variants of human $\mathrm{OX}_{1}$ and $\mathrm{OX}_{2}$ receptors (Figure 1) have not been implicated in human narcolepsy [1,10], genetic variants of the $\mathrm{OX}_{1}$ and $\mathrm{OX}_{2}$ have been inconsistently and weakly associated with many CNS disorders (Table 1, Table 2) including sleep-wake dysregulation, polydipsia in schizophrenia $[13,14]$, panic disorder [15], mood disorders [12], migraine [11,16] and cluster headache [17-20,42]. The relevance of human $\mathrm{OX}_{1}$ and $\mathrm{OX}_{2}$ receptor variants to disease states, identified originally using candidate gene methodologies [5,43], is subject to confirmation by the methods of next generation sequencing [44] that we pioneered to great effect in rare diseases such as Mabry syndrome [45]. Confirmation that naturally occurring orexin variants are functional, let alone pathogenic, is debatable; however, study of artificially created orexin receptor variants has provided insight into orexin receptor signalling that may be relevant to functional interactions and/or heterodimerization with other receptors, such as the cannabinoid $\mathrm{CB}_{1}$ receptor.
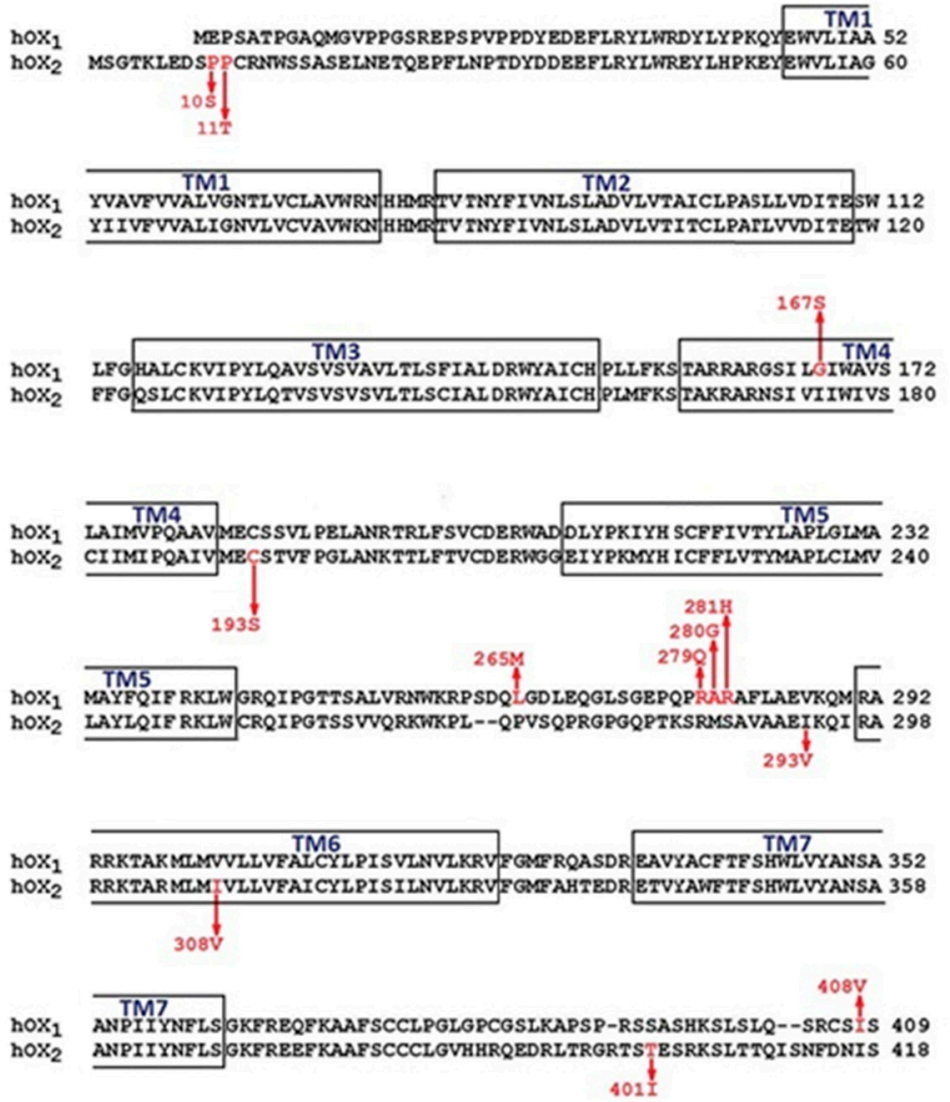

$\begin{array}{lll}\text { hOX }_{1} & \text { KISEHVVLTSVTTVLP } & 425 \\ \text { hOX } & \text { KLSEQVVLTSIST-LPAANGAGPLQNW } & \mathbf{4 4 4}\end{array}$

Figure 1. Alignment of the human $\mathrm{OX}_{1}$ and $\mathrm{OX}_{2}$ receptor amino acid sequences. The common wild-type sequence of $\mathrm{OX}_{1}$ receptor is shown (top) and the common wild-type sequence of $\mathrm{OX}_{2}$ is shown (bottom). Arrows mark the location of known amino acid variants in relation to transmembrane regions 1-7 (TM1-TM7). Alignment adapted from Alscript output [46]. 


\section{Orexin Signalling}

The potential for orexin receptors to functionally interact with other GPCRs or to homo- and/or heterodimerize or oligomerize will be presented after we review the structure and function of wild-type and variant the $\mathrm{OX}_{1}$ (Figure 2) and $\mathrm{OX}_{2}$ (Figure 3) receptors with respect to their signalling properties.

\subsection{Coupling to G Proteins and Other Effectors}

An understanding of which orexin receptor is able to couple to which $G$ protein is integral to a discussion of orexin pharmacology. The interaction of GPCRs with intracellular signal transducers usually takes place via the 2nd and/or 3rd intracellular loops and/or the C-terminus, however, it can sometimes result from interaction with the 1st intracellular loop [47]. Variations in these regions of orexin receptors could impact signalling directly by eliminating the necessary amino acid motifs or indirectly as a result of alterations in the receptor configuration $[5,48,49]$. Unfortunately, there are no data available on the actual $G$ protein interaction sites in orexin receptors. However, $\beta$-arrestin $\left(\mathrm{OX}_{1}\right.$ and $\left.\mathrm{OX}_{2}\right)$ and dynein light chain Tctex-type $1\left(\mathrm{OX}_{1}\right)$ are reported to couple to the orexin receptor C-terminus [50-52] and the Tyr phosphatase SHP-2 to the first intracellular loop $\left(\mathrm{OX}_{1}\right)$ [53]. Based on the knowledge of GPCRs in general, some of the known variants, such as $\mathrm{OX}_{1}^{265}, \mathrm{OX}_{1}^{279}$, $\mathrm{OX}_{1}^{280}, \mathrm{OX}_{1}^{281}, \mathrm{OX}_{1}^{408}, \mathrm{OX}_{2}^{293}$, and $\mathrm{OX}_{2}{ }^{401}$ (Figure 1), could be implicated in $\mathrm{G}$ protein and other protein coupling.

The orexin receptors bind their synthetic small molecular ligands in a partially hydrophilic, partially hydrophobic cleft $[39,40]$. The binding location of orexin peptides is not known, but is assumed to take place in a similar manner, with the conserved peptide C-terminus entering into the cleft. The N-terminus of the orexin peptide is then predicted to protrude from the cleft [41]. Thus, the extracellular portions of the receptor may also contribute to peptide binding: a phenomenon deduced from the OX2R structure that helped to develop a pharmacophore model of binding modes.

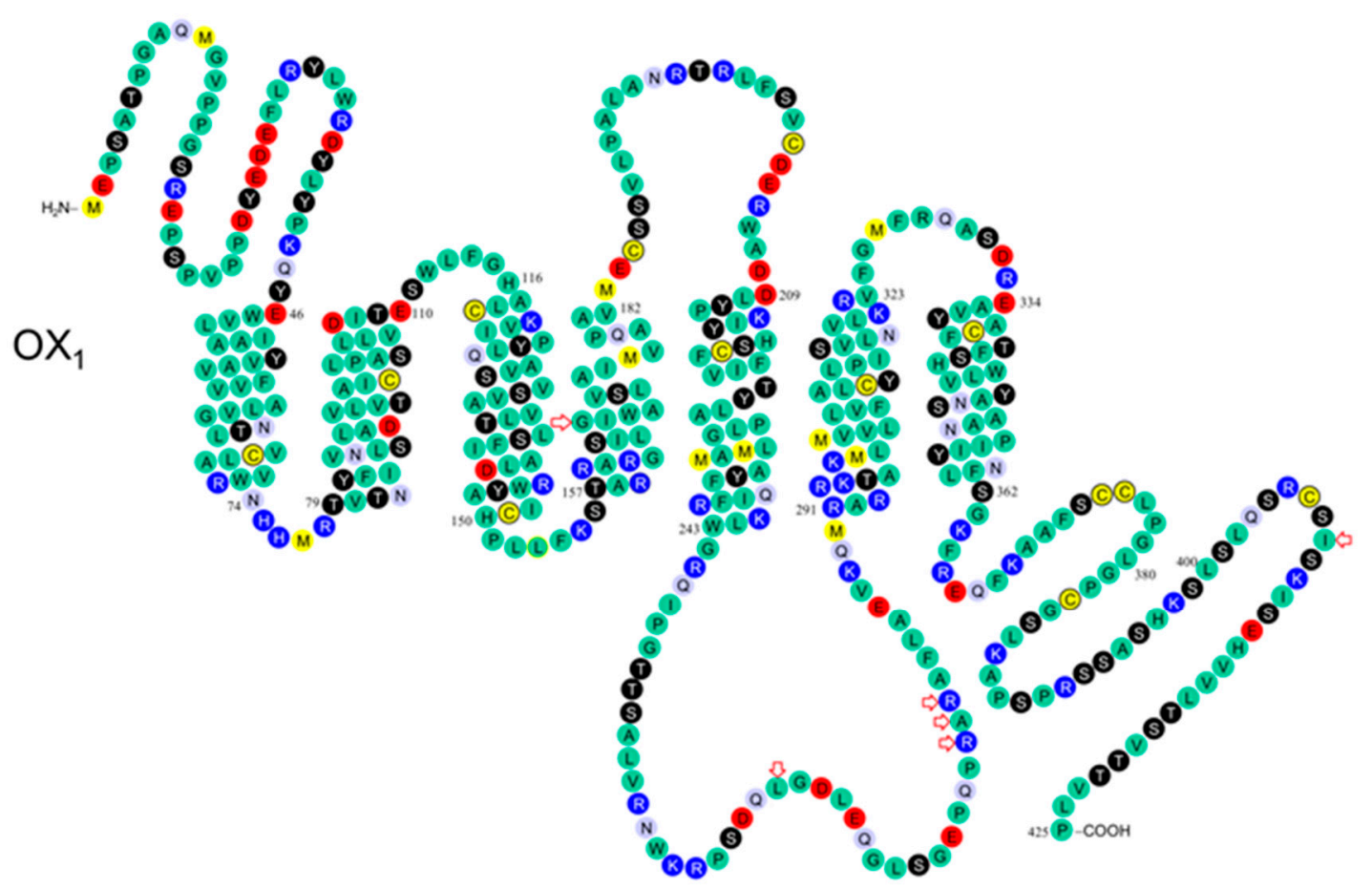

Figure 2. Schematic of the $\mathrm{OX}_{1}$ receptor in the plasma membrane. Modified from Kukkonen et al. [23]; based on findings of Peyron et al. [10] and Olafsdottir et al. [9]. The variants marked with red arrows are: $\mathrm{OX}_{1} 167 \mathrm{Gly} / \mathrm{Ser}, \mathrm{OX}_{1} 265 \mathrm{Leu} / \mathrm{Met}, \mathrm{OX}_{1} 279 \mathrm{Arg} / \mathrm{Glu}, \mathrm{OX}_{1} 280 \mathrm{Ala} / \mathrm{Gly}, \mathrm{OX}_{1} 281 \mathrm{Arg} / \mathrm{His}, \mathrm{OX}_{1} 408$ Ile/Val [2]. 


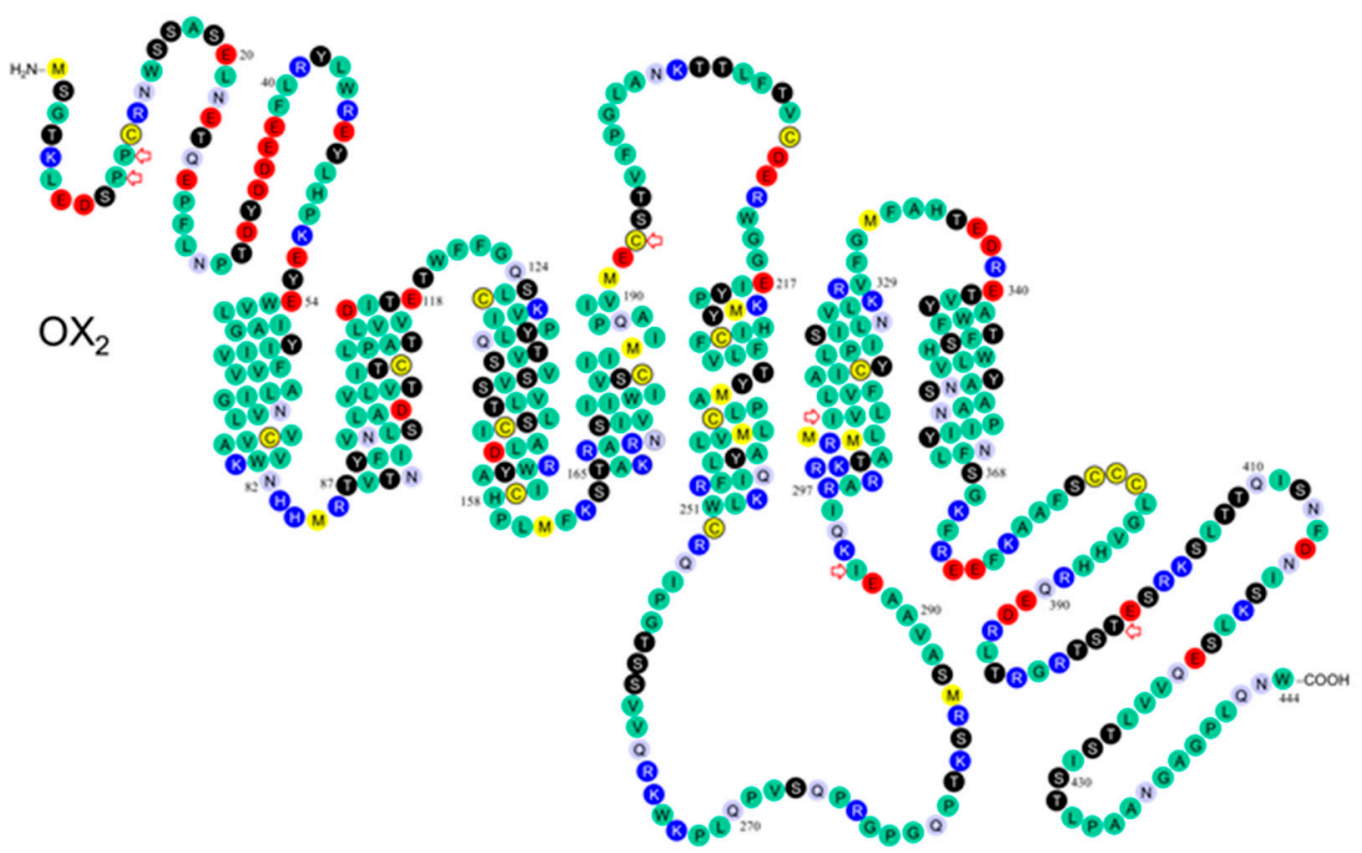

Figure 3. Schematic of the $\mathrm{OX}_{2}$ receptor in the plasma membrane. Modified from Kukkonen et al. [23]; based on findings of Peyron et al. [10] and Olafsdottir et al. [9]. The variants marked with red arrows are: $\mathrm{OX}_{2} 10$ Pro/Ser, $\mathrm{OX}_{2} 11$ Pro/Thr, OX 2193 Cys/Ser, OX 293 Ile/Val, OX 2308 Ile/Val, and OX 401 Thr/Ile [2].

In recombinant systems, the $\mathrm{OX}_{1}$ and $\mathrm{OX}_{2}$ receptors can easily couple to $\mathrm{G}_{\mathrm{i} / \mathrm{o}}$, $\mathrm{G}_{\mathrm{s}}$, and $\mathrm{G}_{\mathrm{q}}$ families $\left(G_{12 / 13}\right.$ not assessed) and $\beta$-arrestin [50,51,54-57]. Similarly, in endogenous cells, orexin receptors are likely capable of coupling to all these $G$ protein families, but the interactions may be subject to species-, tissue- and context-specific regulation [23]. For instance, $\mathrm{OX}_{2}$ receptors in human adrenal cortex activate $\mathrm{G}_{\mathrm{i}}, \mathrm{G}_{\mathrm{s}}$, and $\mathrm{G}_{\mathrm{q}}$ proteins [58]. Mixed orexin receptor populations in rat adrenal cortex or hypothalamus couple to $\mathrm{G}_{\mathrm{i}}, \mathrm{G}_{\mathrm{o}}, \mathrm{G}_{\mathrm{s}}$, and $\mathrm{G}_{\mathrm{q}}$ [31]. Factors influencing signalling cascades have been reviewed in detail elsewhere $[6,7,23,59,60]$.

\subsection{Post-Translational Modifications}

It is difficult to predict sites affecting receptor folding. In principle, however, every residue can influence receptor folding at the local or a more general level. A major change in the amino acid size, conformation, polarity and, especially, charge is likely to have a more pronounced effect. Glycosylation, found on the extracellular orexin GPCR surfaces, could be affected by the availability of Asn and Ser/Thr residues (and other sites in the putative consensus sequence) $[2,61]$. This could be relevant for the $\mathrm{OX}_{2}{ }^{10} \mathrm{Pro} / \mathrm{Ser}, \mathrm{OX}_{2}{ }^{11} \mathrm{Pro} / \mathrm{Thr}$, and $\mathrm{OX}_{2}{ }^{193} \mathrm{Cys} /$ Ser variants (Figure 1).

In humans, polymorphisms in the $\mathrm{N}$-terminal of $\mathrm{OX}_{2}$ include the Pro10Ser and Pro11Thr variants (Figures 1 and 2) described previously [5,62]. These variants may directly affect ligand binding, or indirectly affect ligand binding by altering receptor structure. However, the effects may be equivocal since the termini and loops connecting transmembrane helices are variable by comparison to the transmembrane core of rhodopsin family GPCRs. No mutagenesis studies have been conducted on orexin receptor N-termini.

We review the pharmacology of the $\mathrm{OX}_{2}$ Pro10Ser variant before suggesting a rational for examining the $\mathrm{OX}_{2}{ }^{193}$ Cys/Ser (transmembrane helix 4 (TM4)) variant, the $\mathrm{OX}_{1}{ }^{167}$ Gly/Ser (TM4) variant and the less interesting $\mathrm{OX}_{2}{ }^{308} \mathrm{Ile} / \mathrm{Val}$ (TM6) variant [2]. Thompson et al. identified the $\mathrm{OX}_{2}$ Pro11Thr variant in two DQB1*0602-negative excessive daytime sleepiness (EDS) patients and the $\mathrm{OX}_{2}$ Pro10Ser variant in a Tourette's syndrome patient comorbid with attention deficit hyperactivity 
disorder (ADHD) and probable EDS (Figure 2) [5]. While the $\mathrm{OX}_{2}$ Pro10Ser and $\mathrm{OX}_{2}$ Pro11Thr variants were reported to be more common in human leukocyte antigen (HLA) DQB1*0602-negative narcoleptics compared with controls, Peyron et al. found these variants to be benign with respect to narcolepsy [10].

These variants, however, are known to be rare in the general population (Table 1). The Pro10Ser variant (rs41271312) and the Pro11Thr variant (rs41271310) have been found to have approximate allele frequencies of $0.46 \%$ and $0.26 \%$, respectively. In addition, even rarer polymorphisms have been identified at $\mathrm{OX}_{2}{ }^{10}$ (a Pro10His substitution) and $\mathrm{OX}_{2}{ }^{11}$ (a Pro11Ala substitution). The rarity of these variants in non-EDS populations suggested that their function should be evaluated in vitro [5].

Variations in the sequence of the receptors may have effects apart from ligand binding. Previously, Thompson et al. tested the functional significance of the Pro10Ser and Pro11Thr variants in transfected COS-7 cells by measuring calcium elevation [5]. The results suggested that $\mathrm{OX}_{2}$ Pro10Ser variant may be an example of a pharmacogenetic variant, though we cannot be sure that decreases in efficacy and potency of orexin peptides at these variant $\mathrm{OX}_{2}$ receptors result from altered receptor expression levels. However, there is a lack of conservation at these amino acid positions in the dog, rat and mouse compared with the human wild-type: suggesting degeneracy at these positions. The conservation of proline residues in general [63] and between species [64] suggests they may influence receptor structure and function: possibly because proline residues are known to induce kinks in peptide chains and disrupt $\alpha$-helix and $\beta$-sheet structures.

\subsection{Binding Pocket}

Out of the 11 amino acid variants discussed in this review, the majority are not found within the small molecule binding pocket $[39,40]$. Variant $\mathrm{OX}_{1}{ }^{167}$ harbors an alteration in TM4 close to the intracellular region of the receptor, $\mathrm{OX}_{2}{ }^{193}$ results in an alteration in TM4 and $\mathrm{OX}_{2}{ }^{308}$ is located in TM6 (Figure 1). The latter two sites are less likely to affect ligand binding directly as they point away from the binding cavity $[39,40]$.

Variations of the orexin receptors have also been found in regions located outside the predicted binding cavity that may also have consequences on the binding affinities measured in pharmacological assays. These variants include the canine $\mathrm{OX}_{2}$ Glu54Lys mutation [24] which has been identified in narcoleptic animals. It is possible that human variants of the N-terminal part of the receptor, such as at $\mathrm{OX}_{2}{ }^{10}$, may also influence binding indirectly due to conformational changes or the altered capacity of receptors to homo- and heterodimerize.

The different roles of the two orexin peptides and the two orexin receptors have yet to be fully explained. The respective roles of each peptide may be distinguished by expressing variant copies of one or more orexin receptor polymorphism. In addition to ligand binding differences, co-expression of the variant receptors in heterologous expression systems may allow identification of the domains in each receptor that define homo- and heteromerization.

It is possible that phosphorylation events that regulate receptor desensitization in response to ligand may be altered in a number of orexin receptor variants. Hydroxyl group-containing amino acids Ser, Thr and Tyr are putative substrates for phosphorylation, while other amino acid variations may affect the kinase consensus sequences [49]. Although these sites have not yet been targeted by point mutagenesis studies, a Scansite (http:/ / scansite.mit.edu/) motif search suggests that polymorphisms at $\mathrm{OX}_{1}{ }^{167}, \mathrm{OX}_{1}{ }^{265}, \mathrm{OX}_{1}{ }^{279}, \mathrm{OX}_{1}{ }^{280}, \mathrm{OX}_{1}{ }^{408}$, and $\mathrm{OX}_{2}{ }^{401}$ (Figure 1) may be worth examining.

\section{Modelling Orexin Receptor Hetero- and Homodimerization}

Our discussion of the trafficking, ligand interaction and signalling of the orexin receptors must consider the fact that GPCRs have been shown to dimerize. GPCRs were originally assumed to exist as monomers: a view that has since been revised. More recent models tend to predict that all functional GPCRs form dimers and oligomers [47,65]. Although orexin receptors may form homodimers, heterodimers or even higher order oligomers [66-69], in recombinant expression systems, 
the number of monomers in each complex is difficult to assess. Manipulation of artificial and naturally occurring variants of both $\mathrm{OX}_{1}$ and $\mathrm{OX}_{2}$ may provide a means of examining the receptor domains necessary for multimerization. This strategy has been proposed to explain how a given phenotype, such as asthma [70-73], may result from functional interactions and/or multimerizations of variant cysteinyl leukotriene receptors [74].

With respect to $\mathrm{OX}_{1}$ and $\mathrm{OX}_{2}$, multimerization may influence pharmacological properties such as the affinity for native and synthetic ligands and receptor localization and trafficking. Although there is currently little physiological evidence of its significance, orexin pharmacology may be modulated by the formation of $\mathrm{OX}_{1}-\mathrm{OX}_{2}$ heteromers. Since there is evidence of orexin $\mathrm{OX}_{1}$ and $\mathrm{OX}_{2}$ receptor co-expression in at least some tissues [75], there is an opportunity for multimerization to take place. While the many GPCRs expressed in any given cell represent potential heteromerization partners for orexin receptors, it can be difficult to assess which are physiologically relevant.

The occasional inconsistencies in the results of homo- and heteromerization studies may reflect limitations in the methods. The techniques most often used to assess dimerization are the resonance energy transfer-based techniques, fluorescence resonance energy transfer (FRET) and bioluminescence resonance energy transfer (BRET). However, they cannot be used to show or exclude higher order complexes. While these methods are intended to assay the ability of receptors to form both homomeric and heteromeric complexes, heteromers may have radically different pharmacology, signalling and trafficking properties by comparison to homomeric ones [6,47]. Furthermore, FRET and BRET methods do not easily indicate the efficiency of the complex formation. Resonance energy transfer efficiency is dependent on the orientation and distance of the donor and acceptor. Any change in receptor conformation, irrespective of whether it leads to receptor activation or not, may or may not influence the efficiency of energy transfer $[66,68,69,76,77]$. Thus a difference in efficiency of energy transfer or lack thereof may be of little predictive value.

The impact of naturally occurring variants, such as $\mathrm{OX}_{1}{ }^{408} \mathrm{Ile} / \mathrm{Val}$ and $\mathrm{OX}_{2}{ }^{401} \mathrm{Thr} / \mathrm{Ile}$ (Figure 1), on receptor dimerization is unknown; however, the polymorphic sites located within the receptor C-terminus are adjacent to potential palmitoylation sites. Palmitoylation at the cytosolic end of the third intracellular loop has been shown to promote dimerization of $\mu$ opioid receptors while the oligomerization of $\beta_{2}$ adrenoceptors occurs partially via the C-terminus [78,79]. However, dimerization/oligomerization of other GPCRs may be dependent on other domains.

The importance of dimerization/oligomerization for most family A GPCRs is unclear [47,65]. Notable exceptions to this are the opioid receptors, whose pharmacology, signalling and trafficking are significantly affected [80]. With respect to orexin receptors, early evidence suggested that heterodimerization between $\mathrm{CB}_{1}$ cannabinoid receptors and $\mathrm{OX}_{1}$ may strongly potentiate orexin receptor signalling. However, as we will discuss shortly, it is more likely that signal potentiation depends on the ability of $\mathrm{OX}_{1}$ receptor signalling to elicit the production of $\mathrm{CB}_{1}$ receptor ligands: thereby accounting for $\mathrm{OX}_{1}$ and $\mathrm{CB}_{1}$ receptor co-signalling [60,81-83]. While present evidence does not preclude dimerization, it may suggest that the phenomenon is of limited physiological significance.

\subsection{Evidence for Orexin Receptor Dimerization}

The significance of disrupting motifs necessary for family A GPCR dimerization is not clear [84-86] by comparison with evidence of the deleterious effects of disrupting motifs critical to family C GPCRs dimerization $[87,88]$. One reason is the limited availability of anti-GPCR antibodies in general and anti-orexin receptors in particular. It is common for antibodies to orexin receptors not to bind well or to bind equally well to cells regardless of receptor expression.

The study by $\mathrm{Xu}$ et al. provided some evidence for ligand-enhanced $\mathrm{OX}_{1}$ homomerization. Orexin-A was found to enhance di-/oligomerization, while antagonists reduced di-/oligomerization below basal levels [66]. OX 1 activation enhanced the FRET signal only under conditions of low receptor expression. This is consistent with the idea that dimerization/oligomerization is a dynamically 
regulated process [86,89]. As has previously been reported for a number of family A GPCRs, the process of heterodimerization has been implicated in maturation and cell surface trafficking [90,91].

It has been difficult, however, to prove any significant agonist-mediated impact on the process. Since studies of the functional interactions between human orexin receptor variants are not available, data on mouse orexin receptors may provide insight into the human system. Two splice variants of the mouse $\mathrm{OX}_{2}$ receptor, $\mathrm{OX}_{2 \alpha}$ and $\mathrm{OX}_{2 \beta}$ [92], differing by 17 amino acids in the C-terminus, have been used to explore this phenomenon. Wang et al. demonstrated that splice variants heterodimerize much more efficiently than homodimerize, as indicated by BRET studies [68]. Furthermore, functional $\mathrm{mOX}_{2}$ heterodimers elevated intracellular $\mathrm{Ca}^{2+}$ and activated ERK.

Assuming the lessons from the heterodimerization of mouse $\mathrm{OX}_{2}$ receptor variants are relevant to human orexin receptors, the data from Wang et al. [68] seems to suggest that, like the $\delta$-opioid and somatostatin receptors $[93,94], \mathrm{OX}_{2}$ dimerization may predominantly involve the C-terminal domain. In particular, the $\mathrm{C}$-terminus of the variant $\mathrm{mOX}_{2}$ receptor may be similar to that of the $\delta$-opioid receptor [93]: in which a 15 amino acid C-terminal deletion is also not able to dimerize. This seems likely, since either human orexin receptor subtype interacts with GPR103, as identified by BRET and FRET, in a manner similar to that of $\mathrm{mOX}_{2}$ heterodimers. Furthermore, similar to $\mathrm{mOX}_{2}$ heterodimer signalling through ERK activation, cells co-expressing orexin receptors and GPR103 are noted to produce ERK1/2 phosphorylation when stimulated by either orexin or the GRP103 agonist, QRFP: an effect that was blocked by orexin receptor antagonists [68].

Evaluating the physiological relevance of receptor multimers is important. Even though tools such as selective ligands, membrane-permeant peptides or antibodies can sometimes detect receptor dimers and oligomers, it is possible that heterodimerization is not always possible. Most importantly, the differential expression of $\operatorname{mOX}_{2 \alpha}$ and $\operatorname{mOX}_{2 \beta}$ may preclude heterodimerization.

\subsection{Evidence for $O \mathrm{X}_{1}-\mathrm{CRF} F_{1}$ Receptor Dimerization}

Our understanding of the interaction between $\mathrm{OX}_{1}$, the $\mathrm{CRF}_{1}$ corticotropin-releasing factor receptor and the non-GPCR $\sigma 1$ receptor [95] provides further insight into the mechanisms of receptor cross-talk. Navarro et al. presented a FRET analysis of the $\mathrm{OX}_{1}-\mathrm{CRF}_{1}$ complex to show that it is subject to cross-antagonism (i.e., the response to agonist of either receptor was blocked by antagonists towards either receptor). By contrast, activation of each receptor resulted in negative crosstalk between the receptor responses: despite the fact that activation of each receptor alone stimulated coupling to $\beta$-arrestin and phosphorylation of protein kinase B and ERK1/2. These effects were shown to be blocked by cell-permeable peptides composed of either the OX 1 receptor TM1 or -5 [95].

Evidence of the physiological relevance of the interaction between $\mathrm{OX}_{1}$ and $\mathrm{CRF}_{1}$ was consistent with dopamine release from ventral tegmental area (VTA) upon orexin-A stimulation: a response that was inhibited by antagonists of both $\mathrm{OX}_{1}$ and $\mathrm{CRF}_{1}$ receptors, and by CRF itself. When $\sigma 1$ receptors were stimulated, $\mathrm{OX}_{1}$ and $\mathrm{CRF}_{1}$ receptors were freed from cross-antagonism and negative crosstalk, suggesting a native $\mathrm{OX}_{1}-\mathrm{CRF} 1-\sigma 1$ interaction. Upon activation of the $\sigma 1$ receptors, $\mathrm{CRF}_{1}$ no longer inhibited the $\mathrm{OX}_{1}$-stimulated dopamine release. The total dopamine release was higher upon stimulation of both $\sigma 1$ and $\mathrm{OX}_{1}$ receptors compared with stimulation of $\mathrm{OX}_{1}$ receptors alone [95]: suggesting the physiological and pharmacological significance of the interaction. Collectively, these results suggest that $\mathrm{OX}_{1}$ receptor complex formation with other receptors, such as the $\mathrm{CRF}_{1}$ or GPR103, may be very efficient.

\section{3. $O X_{1}$ Orexin Receptor and $\kappa$ Opioid Receptor ( $\kappa O R$ ) Heteromerization}

Evidence of receptor co-localization suggests the possibility of $\mathrm{OX}_{1}-\mathrm{kOR}$ receptor heteromerization that may have clinical relevance. The balance of orexin peptide signalling through either the $\mathrm{OX}_{1}$ or the $\mathrm{OX}_{2}$ may influence anti-depressant or pro-depressant effects [96]. Physiological evidence implicates orexins in the regulation of emotion. For example, reduced cerebrospinal orexin levels and reduced diurnal orexin fluctuations have been reported in patients with depression [97] and 
decreased $\mathrm{OX}_{1}$ activity may worsen depression in a chronic unpredictable mild stress (CUMS) mouse model [98].

In this context, it is interesting that excessive activation of $\mathrm{KOR}$ induces not depression but anxious and fearful behaviour in both humans and rodents [99]. While the contribution of variant receptors to these processes is unknown, the system may be regulated by heterodimerization [96] and/or functional interaction [6]. For example, the putative orexin receptor interaction with $\mathrm{kOR}$ may modulate pain, stress responses and conditions such as addiction, depression, and schizophrenia [100]. These effects might be indirect. For example, it has been proposed that $\mathrm{KOR}$ stimulation inhibits $\mathrm{OX}_{1}$ activation in dopaminergic neurons [77].

Some studies suggest that the functional interaction occurs purely through an intracellular signalling pathway in which the $\mathrm{OX}_{1}$ receptor activation enhances c-Jun N-terminal kinase (JNK) - mediated phosphorylation of $\mathrm{KOR}$. In CHO-K1 cells, this would have the effect of inhibiting adenylyl cyclase $\mathrm{KOR}$ signalling and enhancing its signalling via $\beta$-arrestin and p38 MAPK, apparently via $\mathrm{G}_{\mathrm{q} / 11}$ [101]. While this may be consistent with evidence that orexin and dynorphin neuropeptides negatively regulate one another's reward pathways through opposing effects in the VTA [102], whether this is a functionally significant mechanism remains unclear. It is also worth taking into consideration that essentially all orexinergic neurons co-express dynorphin (though the reverse is not true).

While $\mathrm{KOR}$ monomers signal mainly through activation of $\mathrm{G}_{\mathrm{i} / \mathrm{o}}$ [103], their dimerization with $\mathrm{OX}_{1}$ may result in "opposite" signalling through $\mathrm{G}_{\mathrm{s}}$ [77]. Co-localization findings suggest that normal $\mathrm{OX}_{1}$ and $\mathrm{KOR}$ homo- and heterodimerization may coordinate signalling responses through the co-release of peptides in regions such as the hypothalamus [61]. This conclusion is consistent with evidence that $\mathrm{OX}_{1}$ and $\mathrm{kOR}$ co-expression in hippocampal neurons is less extensive in depressed rats than in normal rats [104]. In this context, it is intriguing that Chen et al. reported that heteromerization reduced the coupling of $O X_{1}$ and $k O R$ to $G_{q}$ and $G_{i}$, respectively, while it instigated coupling of the receptor heteromers to $\mathrm{G}_{\mathrm{s}}$. Taken together, this would elevate cAMP production in HEK293 cells. Similarly, $\mathrm{Li}$ et al. showed that heterodimerization of the apelin receptor and $\mathrm{KOR}$ increased cAMP accumulation after treatment with either class of ligand [76].

Having presented a critical review of the homo- and heterodimerization literature for the orexins and other systems, such as opioid and $\mathrm{CRF}_{1}$ receptors, we will examine evidence for the functional interaction of $\mathrm{OX}_{1}$ and the $\mathrm{CB}_{1}$ cannabinoid receptor in the context of its potential clinical relevance.

\subsection{Interaction of $O X_{1}$ Receptors and $C B_{1}$ Cannabinoid Receptors}

The $\mathrm{CB}_{1}$ cannabinoid receptor has been shown to heterodimerize with other class A GPCRs, including $\mathrm{D}_{2}$ dopamine [85], opioid [105], adenosine $\mathrm{A} 2 \mathrm{~A}$ [106] and $\mathrm{AT}_{1}$ angiotensin [107] receptors. In addition to other heterodimerization partners, human $\mathrm{OX}_{1}$ and $\mathrm{OX}_{2}$ receptors have been reported to heterodimerize with $\mathrm{CB}_{1}$ cannabinoid receptors $[60,69]$. In contrast to the more discrete hippocampal expression of the orexins, the widespread expression of the endocannabinoid system in general, and the $\mathrm{CB}_{1}$ receptor in particular, allows ample opportunity for co-expression of the receptors and interactions of the systems.

Physiologically, orexins and endocannabinoids may have overlapping functions. The endocannabinoids, lipid metabolites such as 2-arachidonoyl glycerol (2-AG) and anandamide, are native ligands of $\mathrm{CB}_{1}$ cannabinoid receptors. They regulate many physiological functions including analgesia, appetite, learning and memory [108]. Furthermore, orexin receptor signalling may trigger production of 2-AG, leading to the activation of the $\mathrm{CB}_{1}$ receptor [60,81-83]. In vitro, the human $\mathrm{OX}_{1}$ forms heteromeric complexes with $\mathrm{CB}_{1}$ receptors $[67,69,109]$ that, if present in vivo, may be influenced by receptor variants. Furthermore, heteromultimerization of $\mathrm{CB}_{1}$ and $\mathrm{OX}_{1}$ receptors has been reported to be subject to orexin-A feedback involving the both receptors [67].

The data from Jäntti et al. shows that both orexin receptor subtypes are capable of forming constitutive homo- and heteromeric complexes with one-another and with $\mathrm{CB}_{1}$ cannabinoid receptors [69]. However, while dimerization is possible, the data suggest that the downstream 
effect on signalling may result as much from a functional interaction than a molecular interaction of the receptors $[60,61,82]$. In the case of $\mathrm{OX}_{1}-\mathrm{CB}_{1}$ interaction, Jäntti et al. reported that the major part, if not all, of the interaction results from orexin-promoted 2-AG production and not from heterodimerization [60]. However, no receptor dimerization-blocking peptides have been used to assay this interaction.

Using a BRET assay, Jäntti et al. found that $\mathrm{CB}_{1}$ receptors readily homodimerize and heterodimerize with $\mathrm{OX}_{1}$ and $\mathrm{OX}_{2}$ receptors (Figure 4). Homomeric complexes of $\mathrm{OX}_{1}, \mathrm{OX}_{2}$ and $\mathrm{CB}_{1}$ showed the best $\mathrm{BRET}$ efficacy in this study. While the evidence for $\mathrm{OX}_{1}-\mathrm{CB}_{1}$ receptor interaction was similar to that for $\mathrm{OX}_{1}$ and $\mathrm{OX}_{2}$ receptors, the evidence for $\mathrm{CB}_{1}$ and $\mathrm{OX}_{2}$ receptor interaction was weaker (Figure 4) [69]. When constitutive $\mathrm{CB}_{1}-\mathrm{OX}_{2}$ complexes were tested for a possible change upon orexin stimulation, only a minor $(<10 \%)$ reduction in BRET was reported. These studies highlight the issue of GPCR dimer stability. Since geometry limits the use of FRET or BRET efficiency to assess affinity for complex formation, different receptor combinations cannot be compared quantitatively. This is clearly illustrated in Figure 4, which shows that BRET efficiency can vary depending on which partner of the heteromer harbors which BRET component. While these results establish that such complexes can be formed, they do not indicate that they are actually present and function in cells in situ.

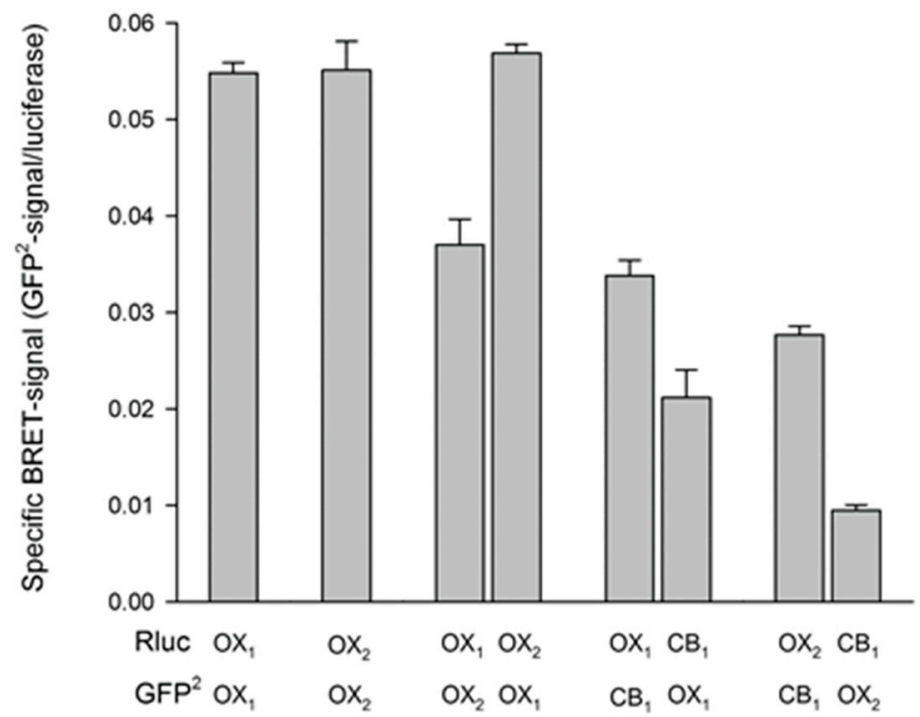

Figure 4. Human orexin and cannabinoid receptor interactions as measured utilizing BRET (BRET $\left.{ }^{2}\right)$ between renilla luciferase (Rluc) and $\mathrm{GFP}^{2}$ fused to the receptors' C-termini. The Rluc background has been subtracted from the values. The data presented are the mean $\pm \mathrm{SE} ; \mathrm{n}$ refers to the number of cell batches. Each experiment was performed at least three times in 4-6 replicates. The data originate from Jantti et al. [69].

In conclusion, both orexin receptor subtypes and $\mathrm{CB}_{1}$ cannabinoid receptors are capable of forming constitutive homo- and heteromeric complexes that may be relevant to orexin signalling. Whether these complexes are physiologically functional and whether they are dynamically regulated, however, remains to be shown. The so-called bivalent ligands, however, represent a possible way of determining their physiological significance. Although ligands, such as those designed for the $\mathrm{CB}_{1}$ receptor dimers $[110,111]$, may show some selectivity for the receptor homo- or heterodimers, no agonists specific to putative orexin- $\mathrm{CB}_{1}$ heterodimers exist currently. In fact, the data suggest that the effect of orexin potentiation of $\mathrm{CB}_{1}$ signalling may not result from heterodimerization but, instead, result from orexin-promoted 2-AG production (see above). The extent to which functional interactions can explain the putative confluence of orexin and cannabinoid systems better than receptor heterodimerization is important due to the potential for such an interaction to influence pharmacology. 


\section{Relevance of $\mathrm{CB}_{1} / \mathrm{OX}_{1}$ Expression in the Hippocampus to Disease}

A number of studies have demonstrated molecular and functional cross-talk between $\mathrm{CB}_{1}$ and $\mathrm{OX}_{1}$ receptors in heterologous expression systems. Evidence of functional crosstalk suggests that $\mathrm{CB}_{1}-\mathrm{OX}_{1}$ interaction may take place in the neuronal membranes at nerve terminals in many brain regions. This is especially true in the hippocampus [112], where co-expression of $\mathrm{CB}_{1}$ and $\mathrm{OX}_{1}$ is in evidence. In view of this, changes in $\mathrm{CB}_{1} / \mathrm{OX}_{1}$ expression may be a biomarker for $\mathrm{CNS}$ disease in certain brain regions.

Recently, the problem of pharmacoresistance in status epilepticus (SE) has generated interest in developing novel pharmacological interventions that will limit the damage that develops as seizure duration increases during pharmacoresistance $[113,114]$. This is not only the case for traditional benzodiazepine drugs, since over $40 \%$ of SE cases are refractory to initial treatment with two or more medications [113]: rendering SE a life-threatening neurological condition.

Safety concerns have historically led to restrictions in the medicinal use of marijuana [115]. In some recent studies, however, cannabinoids have been implicated in epileptogenesis. While $\triangle 9$-tetrahydrocannabinolic acid (THC) itself may be proconvulsant under some circumstances, the efficacy of drugs such as cannabidiol (CBD), that do not primarily target $\mathrm{CB}_{1}$ receptors [4], suggests the therapeutic potential of cannabinoids. Physiological studies suggest that endogenous cannabinoids in the hippocampus act as retrograde messengers from depolarized postsynaptic neurons to presynaptic terminals [116]. This may result in depolarization-induced suppression of inhibition (DSI); although homo- and heterosynaptic depolarization-induced suppression of excitation (DSE), and cannabinoid-mediated plasticity are also possible.

In human subjects, downregulation of $\mathrm{CB}_{1}$ receptors has been reported in epileptic hippocampal tissue [117]. Consistent with this, Falenski et al. found reduced $\mathrm{CB}_{1}$ levels in the rat hippocampus following $\mathrm{SE}$ in the pilocarpine model [118]. However, Bojnik et al. found an elevation in $\mathrm{CB}_{1}$ expression in the kainic acid model [119] that may be consistent with evidence that $\mathrm{CB}_{1}$ agonists protect against the excitotoxic injury induced by kainic acid [120].

There is evidence that, at least under some circumstances, orexinergic neurons are under the control of presynaptic $\mathrm{CB}_{1}$ receptor-regulated inputs [78,121]. The long-term effects of kainic acid-induced $\mathrm{SE}$ on $\mathrm{CB}_{1}$ and $\mathrm{OX}_{1}$ expression in rat hippocampus has been examined. $\mathrm{CB}_{1}$ expression in the hippocampus increased after SE, as measured by immunohistochemistry and RT-PCR [112]. However, Zhu et al. did not report an increase in $\mathrm{OX}_{1}$ expression after SE: an observation that may reflect the fact that antibodies to $\mathrm{OX}_{1}$ do not always perform well (personal observations). Although it is doubtful that, even with further testing, THC or the present generation of orexinergic drugs would, themselves, be useful as anticonvulsants, changes in putative $\mathrm{CB}_{1} / \mathrm{OX}_{1}$ interaction may reflect $\mathrm{CNS}$ pathogenesis that may be relevant to pharmacology.

By contrast with the cannabinoids, data showing the seizure-modulating role of orexins are still emerging. For example, Doreulee et al. reported the possible involvement of the orexinergic system in antiepileptic mechanisms [122]. On the other hand, other studies have reported behavioural seizure activity when orexin peptides were injected ICV into rats [29].

The overlap in $\mathrm{CB}_{1}$ and $\mathrm{OX}_{1}$ distribution in nerve terminals of the hippocampus may be worth examining with respect to its potential to influence heterodimer formation and epileptogenesis [112]. However, alternative explanations may include the following: (1) The $\mathrm{OX}_{1} / \mathrm{CB}_{1}$ heterodimers in SE merely represent biomarkers that may be of limited specificity in SE or its treatment; and (2) The $\mathrm{OX}_{1} / \mathrm{CB}_{1}$ heterodimers in SE have relevance as novel therapeutic targets, although they do not necessarily reflect the pathobiology of $\mathrm{SE} . \mathrm{CB}_{1}$ and $\mathrm{OX}_{1}$ "cross-talk" in SE, however, may only become clinically useful with the development of novel drugs that target either $\mathrm{OX}_{1}$ or $\mathrm{CB}_{1}$.

\section{Conclusions}

This discussion focuses on an examination of the evidence suggesting that orexin receptor signalling can result from functional interaction and/or homo- and heterodimerization with opioid 
and cannabinoid systems. We presented perspectives on orexin signalling in the context of other neurotransmitter systems implicated in epilepsy and neurodegeneration that could be informative to future work.

Human $\mathrm{OX}_{1}$ orexin receptors have been shown to homodimerize and interact functionally with other receptor types. In particular, the evidence for heterodimerization versus functional interaction for $\mathrm{OX}_{1}$ and $\mathrm{KOR}$ and the $\mathrm{CB}_{1}$ cannabinoid receptors is discussed. While dimerization may be important for orexin receptor responses and trafficking, many physiological effects can be explained through the evidence for functional interactions (i.e., interactions of receptor signal transduction pathways). In this regard, we assess evidence suggesting that orexin receptor activation can result in endocannabinoid production that acts at $\mathrm{CB}_{1}$ receptors.

By contrast, dimerization may be a means whereby signalling is optimized for a given receptor type. For example, complexes may form when optimal cannabinoid concentrations are available for cannabinoid receptors. While orexin receptor subtypes readily form homo- and heteromeric complexes, as suggested by significant BRET signals, it would be unclear whether this takes place in situ except for the few studies have assessed this phenomenon [95]. As a result, ex vivo preparations may be a useful means of examining this in future studies.

The pharmacology of the known orexin receptor variants, especially those located in the carboxyl terminal, such as $\mathrm{OX}_{1}{ }^{408}$ and $\mathrm{OX}_{2}{ }^{401}$ (Tables 1 and 2), are discussed in the context of GPCR signalling; however, their potential impact on orexin receptor homo- and heterodimerization is not known. Since co-expression of $\mathrm{OX}_{1}$ and $\mathrm{OX}_{2}$ receptor variants is relatively common, however, their functional significance is discussed. Given that state of the present knowledge it is unclear if co-expression results in, A. distinct pharmacology through functional interaction, B. distinct pharmacology as a result of the formation of variant heteromers, or C. no change in pharmacology.

The structural insights resulting from resolving the orexin receptor crystal structure [39-41] may clarify many points discussed. To further this endeavor, we contrast evidence supporting the functional interaction versus the heterodimerization hypotheses of orexin receptor interaction with other systems such as cannabinoid receptors. The potential of these interactions to enhance the pharmacological treatment of some neurological conditions such as epilepsy and depression is noted.

Acknowledgments: This work was supported by grants from the Scottish Rite Charitable Foundation of Canada, the Canadian Institutes of Health Research (CIHR), Epilepsy Canada and Rady Children's Hospital (Miles D. Thompson); Saint George's University, Grenada (Mary C. Maj); and the Magnus Ehrnrooth Foundation and the Liv \& Hälsa Foundation (Jyrki P. Kukkonen).

The Canadian Bioceutical Corporation sponsored M.T. to attend the Epilepsy Foundation's workshop on Cannabinoid Signalling in Epilepsy that was held at Stanford University, 9th and 10th October 2017. We thank Christopher Winrow, Ironwood Pharmaceuticals, for useful discussions. The authors would like to acknowledge the Exome Aggregation Consortium and the groups that provided exome variant frequency data for comparison. A full list of contributing groups can be found at http:/ / exac.broadinstitute.org.

Author Contributions: M.T. coordinated the manuscript; J.K. provided expertise in orexin signal transduction and contributed Figures 2-4. M.M. searched functional variants depicted in Figure 1 and contributed to the text; I.R. provided Cluster Headache and Migraine data used in Tables 1 and 2 and T.S. provided the original $\mathrm{OX}_{1}$ and $\mathrm{OX}_{2}$ sequence.

Conflicts of Interest: The authors declare no conflict of interest.

\section{References}

1. Gencik, M.; Dahmen, N.; Wieczorek, S.; Kasten, M.; Bierbrauer, J.; Anghelescu, I.; Szegedi, A.; Menezes Saecker, A.M.; Epplen, J.T. A prepro-orexin gene polymorphism is associated with narcolepsy. Neurology 2001, 56, 115-117. [CrossRef] [PubMed]

2. Thompson, M.D.; Xhaard, H.; Sakurai, T.; Rainero, I.; Kukkonen, J.P. OX1 and OX2 orexin/hypocretin receptor pharmacogenetics. Front. Neurosci. 2014, 8, 57. [CrossRef] [PubMed]

3. Winrow, C.J.; Renger, J.J. Discovery and development of orexin receptor antagonists as therapeutics for insomnia. Br. J. Pharmacol. 2014, 171, 283-293. [CrossRef] [PubMed] 
4. Thompson, M.D.; Cole, D.E.; Capra, V.; Siminovitch, K.A.; Rovati, G.E.; Burnham, W.M.; Rana, B.K. Pharmacogenetics of the G protein-coupled receptors. Methods Mol. Biol. 2014, 1175, 189-242. [PubMed]

5. Thompson, M.D.; Comings, D.E.; Abu-Ghazalah, R.; Jereseh, Y.; Lin, L.; Wade, J.; Sakurai, T.; Tokita, S.; Yoshida, T.; Tanaka, H.; et al. Variants of the orexin2/hcrt2 receptor gene identified in patients with excessive daytime sleepiness and patients with Tourette's syndrome comorbidity. Am. J. Med. Genet. B Neuropsychiatr. Genet. 2004, 129, 69-75. [CrossRef] [PubMed]

6. Kukkonen, J.P. Orexin/hypocretin signalling. Curr. Top Behav. Neurosci. 2017, 33, 17-50. [PubMed]

7. Kukkonen, J.P.; Leonard, C.S. Orexin/hypocretin receptor signalling cascades. Br. J. Pharmacol. 2014, 171, 314-331. [CrossRef] [PubMed]

8. Leonard, C.S.; Kukkonen, J.P. Orexin/hypocretin receptor signalling: A functional perspective. Br. J. Pharmacol. 2014, 171, 294-313. [CrossRef] [PubMed]

9. Olafsdottir, B.R.; Rye, D.B.; Scammell, T.E.; Matheson, J.K.; Stefansson, K.; Gulcher, J.R. Polymorphisms in hypocretin/orexin pathway genes and narcolepsy. Neurology 2001, 57, 1896-1899. [CrossRef] [PubMed]

10. Peyron, C.; Faraco, J.; Rogers, W.; Ripley, B.; Overeem, S.; Charnay, Y.; Nevsimalova, S.; Aldrich, M.; Reynolds, D.; Albin, R.; et al. A mutation in a case of early onset narcolepsy and a generalized absence of hypocretin peptides in human narcoleptic brains. Nat. Med. 2000, 6, 991-997. [PubMed]

11. Rainero, I.; Rubino, E.; Gallone, S.; Fenoglio, P.; Picci, L.R.; Giobbe, L.; Ostacoli, L.; Pinessi, L. Evidence for an association between migraine and the hypocretin receptor 1 gene. J. Headache Pain 2011, 12, 193-199. [CrossRef] [PubMed]

12. Rainero, I.; Ostacoli, L.; Rubino, E.; Gallone, S.; Picci, L.R.; Fenoglio, P.; Negro, E.; Rosso, C.; De Martino, P.; De Marchi, M.; et al. Association between major mood disorders and the hypocretin receptor 1 gene. J. Affect. Disord. 2011, 130, 487-491. [CrossRef] [PubMed]

13. Meerabux, J.; Iwayama, Y.; Sakurai, T.; Ohba, H.; Toyota, T.; Yamada, K.; Nagata, R.; Irukayama-Tomobe, Y.; Shimizu, H.; Yoshitsugu, K.; et al. Association of an orexin 1 receptor 408Val variant with polydipsia-hyponatremia in schizophrenic subjects. Biol. Psychiatry 2005, 58, 401-407. [CrossRef] [PubMed]

14. Fukunaka, Y.; Shinkai, T.; Hwang, R.; Hori, H.; Utsunomiya, K.; Sakata, S.; Naoe, Y.; Shimizu, K.; Matsumoto, C.; Ohmori, O.; et al. The orexin 1 receptor (HCRTR1) gene as a susceptibility gene contributing to polydipsia-hyponatremia in schizophrenia. Neuromol. Med. 2007, 9, 292-297. [CrossRef] [PubMed]

15. Annerbrink, K.; Westberg, L.; Olsson, M.; Andersch, S.; Sjodin, I.; Holm, G.; Allgulander, C.; Eriksson, E. Panic disorder is associated with the Val308Iso polymorphism in the hypocretin receptor gene. Psychiatr. Genet. 2011, 21, 85-89. [CrossRef] [PubMed]

16. Schurks, M.; Limmroth, V.; Geissler, I.; Tessmann, G.; Savidou, I.; Engelbergs, J.; Kurth, T.; Diener, H.C.; Rosskopf, D. Association between migraine and the G1246A polymorphism in the hypocretin receptor 2 gene. Headache 2007, 47, 1195-1199. [CrossRef] [PubMed]

17. Baumber, L.; Sjostrand, C.; Leone, M.; Harty, H.; Bussone, G.; Hillert, J.; Trembath, R.C.; Russell, M.B. A genome-wide scan and HCRTR2 candidate gene analysis in a European cluster headache cohort. Neurology 2006, 66, 1888-1893. [CrossRef] [PubMed]

18. Schurks, M.; Kurth, T.; Geissler, I.; Tessmann, G.; Diener, H.C.; Rosskopf, D. Cluster headache is associated with the G1246A polymorphism in the hypocretin receptor 2 gene. Neurology 2006, 66, 1917-1919. [CrossRef] [PubMed]

19. Rainero, I.; Gallone, S.; Rubino, E.; Ponzo, P.; Valfre, W.; Binello, E.; Fenoglio, P.; Gentile, S.; Anoaica, M.; Gasparini, M.; et al. Haplotype analysis confirms the association between the HCRTR2 gene and cluster headache. Headache 2008, 48, 1108-1114. [CrossRef] [PubMed]

20. Schurks, M.; Kurth, T.; Geissler, I.; Tessmann, G.; Diener, H.C.; Rosskopf, D. The G1246A polymorphism in the hypocretin receptor 2 gene is not associated with treatment response in cluster headache. Cephalalgia 2007, 27, 363-367. [CrossRef] [PubMed]

21. Sakurai, T.; Amemiya, A.; Ishii, M.; Matsuzaki, I.; Chemelli, R.M.; Tanaka, H.; Williams, S.C.; Richardson, J.A.; Kozlowski, G.P.; et al. Orexins and orexin receptors: A family of hypothalamic neuropeptides and G protein-coupled receptors that regulate feeding behavior. Cell 1998, 92, 573-585. [CrossRef]

22. de Lecea, L.; Kilduff, T.S.; Peyron, C.; Gao, X.; Foye, P.E.; Danielson, P.E.; Fukuhara, C.; Battenberg, E.L.; Gautvik, V.T.; Bartlett, F.S. The hypocretins: Hypothalamus-specific peptides with neuroexcitatory activity. Proc. Natl. Acad. Sci. USA 1998, 95, 322-327. [CrossRef] [PubMed] 
23. Kukkonen, J.P. Physiology of the orexinergic/hypocretinergic system: A revisit in 2012. Am. J. Physiol. Cell Physiol. 2013, 304, 2-32. [CrossRef] [PubMed]

24. Lin, L.; Faraco, J.; Li, R.; Kadotani, H.; Rogers, W.; Lin, X.; Qiu, X.; de Jong, P.J.; Nishino, S.; Mignot, E. The sleep disorder canine narcolepsy is caused by a mutation in the hypocretin (orexin) receptor 2 gene. Cell 1999, 98, 365-376. [CrossRef]

25. Hungs, M.; Fan, J.; Lin, L.; Lin, X.; Maki, R.A.; Mignot, E. Identification and functional analysis of mutations in the hypocretin (orexin) genes of narcoleptic canines. Genome Res. 2001, 11, 531-539. [CrossRef] [PubMed]

26. Chemelli, R.M.; Willie, J.T.; Sinton, C.M.; Elmquist, J.K.; Scammell, T.; Lee, C.; Richardson, J.A.; Williams, S.C.; Xiong, Y.; Kisanuki, Y.; et al. Narcolepsy in orexin knockout mice: Molecular genetics of sleep regulation. Cell 1999, 98, 437-451. [CrossRef]

27. Willie, J.T.; Chemelli, R.M.; Sinton, C.M.; Tokita, S.; Williams, S.C.; Kisanuki, Y.Y.; Marcus, J.N.; Lee, C.; Elmquist, J.K.; Kohlmeier, K.A.; et al. Distinct narcolepsy syndromes in Orexin receptor-2 and Orexin null mice: Molecular genetic dissection of non-REM and REM sleep regulatory processes. Neuron 2003, 38, 715-730. [CrossRef]

28. Nishino, S.; Ripley, B.; Overeem, S.; Lammers, G.J.; Mignot, E. Hypocretin (orexin) deficiency in human narcolepsy. Lancet 2000, 355, 39-40. [CrossRef]

29. Ida, T.; Nakahara, K.; Katayama, T.; Murakami, N.; Nakazato, M. Effect of lateral cerebroventricular injection of the appetite-stimulating neuropeptide, orexin and neuropeptide $\mathrm{Y}$, on the various behavioral activities of rats. Brain Res. 1999, 821, 526-529. [CrossRef]

30. Takahashi, N.; Okumura, T.; Yamada, H.; Kohgo, Y. Stimulation of gastric acid secretion by centrally administered orexin-A in conscious rats. Biochem. Biophys. Res. Commun. 1999, 254, 623-627. [CrossRef] [PubMed]

31. Karteris, E.; Machado, R.J.; Chen, J.; Zervou, S.; Hillhouse, E.W.; Randeva, H.S. Food deprivation differentially modulates orexin receptor expression and signalling in rat hypothalamus and adrenal cortex. Am. J. Physiol. Endocrinol. Metab. 2005, 288, E1089-1100. [CrossRef] [PubMed]

32. Malendowicz, L.K.; Tortorella, C.; Nussdorfer, G.G. Orexins stimulate corticosterone secretion of rat adrenocortical cells, through the activation of the adenylate cyclase-dependent signalling cascade. J. Steroid Biochem. Mol. Biol. 1999, 70, 185-188. [CrossRef]

33. Lubkin, M.; Stricker-Krongrad, A. Independent feeding and metabolic actions of orexins in mice. Biochem. Biophys. Res. Commun. 1998, 253, 241-245. [CrossRef] [PubMed]

34. Yamamoto, Y.; Ueta, Y.; Serino, R.; Nomura, M.; Shibuya, I.; Yamashita, H. Effects of food restriction on the hypothalamic prepro-orexin gene expression in genetically obese mice. Brain Res. Bull. 2000, 51, 515-521. [CrossRef]

35. Malherbe, P.; Roche, O.; Marcuz, A.; Kratzeisen, C.; Wettstein, J.G.; Bissantz, C. Mapping the binding pocket of dual antagonist almorexant to human orexin 1 and orexin 2 receptors: Comparison with the selective $\mathrm{OX}_{1}$ antagonist $\mathrm{SB}-674042$ and the selective $\mathrm{OX}_{2}$ antagonist $\mathrm{N}$-ethyl-2-[(6-methoxy-pyridin-3-yl)-(toluene-2-sulfonyl)-amino]- $\mathrm{N}$-pyridin-3-ylmethyl-acetamide (EMPA). Mol. Pharmacol. 2010, 78, 81-93. [PubMed]

36. Putula, J.; Kukkonen, J.P. Mapping of the binding sites for the OX1 orexin receptor antagonist, SB-334867, using orexin/hypocretin receptor chimaeras. Neurosci. Lett. 2012, 506, 111-115. [CrossRef] [PubMed]

37. Tran, D.T.; Bonaventure, P.; Hack, M.; Mirzadegan, T.; Dvorak, C.; Letavic, M.; Carruthers, N.; Lovenberg, T.; Sutton, S.W. Chimeric, mutant orexin receptors show key interactions between orexin receptors, peptides and antagonists. Eur. J. Pharmacol. 2011, 667, 120-128. [CrossRef] [PubMed]

38. Heifetz, A.; Morris, G.B.; Biggin, P.C.; Barker, O.; Fryatt, T.; Bentley, J.; Hallett, D.; Manikowski, D.; Pal, S.; Reifegerste, R.; et al. Study of human Orexin-1 and -2 G-protein-coupled receptors with novel and published antagonists by modeling, molecular dynamics simulations, and site-directed mutagenesis. Biochemistry 2012, 51, 3178-3197. [CrossRef] [PubMed]

39. Yin, J.; Babaoglu, K.; Brautigam, C.A.; Clark, L.; Shao, Z.; Scheuermann, T.H.; Harrell, C.M.; Gotter, A.L.; Roecker, A.J.; Winrow, C.J.; et al. Structure and ligand-binding mechanism of the human OX1 and OX2 orexin receptors. Nat. Struct. Mol. Biol. 2016, 23, 293-299. [CrossRef] [PubMed]

40. Yin, J.; Mobarec, J.C.; Kolb, P.; Rosenbaum, D.M. Crystal structure of the human OX2 orexin receptor bound to the insomnia drug suvorexant. Nature 2015, 519, 247-250. [CrossRef] [PubMed] 
41. Karhu, L.; Turku, A.; Xhaard, H. Modeling of the OX1R-orexin-A complex suggests two alternative binding modes. BMC Struct. Biol. 2015, 15. [CrossRef] [PubMed]

42. Rainero, I.; Gallone, S.; Valfre, W.; Ferrero, M.; Angilella, G.; Rivoiro, C.; Rubino, E.; De Martino, P.; Savi, L.; Ferrone, M.; et al. A polymorphism of the hypocretin receptor 2 gene is associated with cluster headache. Neurology 2004, 63, 1286-1288. [CrossRef] [PubMed]

43. Thompson, M.D.; Bowen, R.A.; Wong, B.Y.; Antal, J.; Liu, Z.; Yu, H.; Siminovitch, K.; Kreiger, N.; Rohan, T.E.; Cole, D.E. Whole genome amplification of buccal cell DNA: Genotyping concordance before and after multiple displacement amplification. Clin. Chem. Lab. Med. 2005, 43, 157-162. [CrossRef] [PubMed]

44. Mardis, E.R. New strategies and emerging technologies for massively parallel sequencing: Applications in medical research. Genome Med. 2009, 1, 40. [CrossRef] [PubMed]

45. Krawitz, P.M.; Schweiger, M.R.; Rodelsperger, C.; Marcelis, C.; Kolsch, U.; Meisel, C.; Stephani, F.; Kinoshita, T.; Murakami, Y.; Bauer, S.; et al. Identity-by-descent filtering of exome sequence data identifies PIGV mutations in hyperphosphatasia mental retardation syndrome. Nat. Genet. 2010, 42, 827-829. [CrossRef] [PubMed]

46. Barton, G.J. ALSCRIPT: A tool to format multiple sequence alignments. Protein Eng. 1993, 6, 37-40. [CrossRef] [PubMed]

47. Milligan, G. G protein-coupled receptor hetero-dimerization: Contribution to pharmacology and function. Br. J. Pharmacol. 2009, 158, 5-14. [CrossRef] [PubMed]

48. Thompson, M.D.; Hendy, G.N.; Percy, M.E.; Bichet, D.G.; Cole, D.E. G protein-coupled receptor mutations and human genetic disease. Methods Mol. Biol. 2014, 1175, 153-187. [PubMed]

49. Thompson, M.D.; Cole, D.E.; Jose, P.A.; Chidiac, P. G protein-coupled receptor accessory proteins and signalling: Pharmacogenomic insights. Methods Mol Biol. 2014, 1175, 121-152. [PubMed]

50. Milasta, S.; Evans, N.A.; Ormiston, L.; Wilson, S.; Lefkowitz, R.J.; Milligan, G. The sustainability of interactions between the orexin-1 receptor and beta-arrestin-2 is defined by a single C-terminal cluster of hydroxy amino acids and modulates the kinetics of ERK MAPK regulation. Biochem. J. 2005, 387, 573-584. [CrossRef] [PubMed]

51. Jaeger, W.C.; Seeber, R.M.; Eidne, K.A.; Pfleger, K.D. Molecular determinants of orexin receptor-arrestin-ubiquitin complex formation. Br. J. Pharmacol. 2014, 171, 364-374. [CrossRef] [PubMed]

52. Duguay, D.; Belanger-Nelson, E.; Mongrain, V.; Beben, A.; Khatchadourian, A.; Cermakian, N. Dynein light chain Tctex-Type 1 modulates orexin signalling through its interaction with orexin 1 receptor. PLoS ONE 2011, 6. [CrossRef] [PubMed]

53. EI Firar, A.; Voisin, T.; Rouyer-Fessard, C.; Ostuni, M.A.; Couvineau, A.; Laburthe, M. Discovery of a functional immunoreceptor tyrosine-based switch motif in a 7-transmembrane-spanning receptor: Role in the orexin receptor OX1R-driven apoptosis. FASEB J. 2009, 23, 4069-4080. [CrossRef] [PubMed]

54. Dalrymple, M.B.; Jaeger, W.C.; Eidne, K.A.; Pfleger, K.D. Temporal profiling of orexin receptor-arrestinubiquitin complexes reveals differences between receptor subtypes. J. Biol. Chem. 2011, 286, 16726-16733. [CrossRef] [PubMed]

55. Holmqvist, T.; Johansson, L.; Ostman, M.; Ammoun, S.; Akerman, K.E.; Kukkonen, J.P. OX1 orexin receptors couple to adenylyl cyclase regulation via multiple mechanisms. J. Biol. Chem. 2005, 280, 6570-6579. [CrossRef] [PubMed]

56. Magga, J.; Bart, G.; Oker-Blom, C.; Kukkonen, J.P.; Akerman, K.E.; Nasman, J. Agonist potency differentiates $\mathrm{G}$ protein activation and $\mathrm{Ca}^{2+}$ signalling by the orexin receptor type 1. Biochem. Pharmacol. 2006, 71, 827-836. [CrossRef] [PubMed]

57. Kukkonen, J.P. OX2 orexin/hypocretin receptor signal transduction in recombinant Chinese hamster ovary cells. Cell. Signal. 2016, 28, 51-60. [CrossRef] [PubMed]

58. Randeva, H.S.; Karteris, E.; Grammatopoulos, D.; Hillhouse, E.W. Expression of orexin-A and functional orexin type 2 receptors in the human adult adrenals: Implications for adrenal function and energy homeostasis. J. Clin. Endocrinol. Metab. 2001, 86, 4808-4813. [CrossRef] [PubMed]

59. Wess, J. Molecular basis of receptor/G-protein-coupling selectivity. Pharmacol. Ther. 1998, 80, $231-264$. [CrossRef] 
60. Jantti, M.H.; Putula, J.; Turunen, P.M.; Nasman, J.; Reijonen, S.; Lindqvist, C.; Kukkonen, J.P. Autocrine endocannabinoid signalling through CB1 receptors potentiates OX1 orexin receptor signalling. Mol. Pharmacol. 2013, 83, 621-632. [CrossRef] [PubMed]

61. Milligan, G.; Canals, M.; Pediani, J.D.; Ellis, J.; Lopez-Gimenez, J.F. The role of GPCR dimerisation/oligomerisation in receptor signalling. In GPCRs: From Deorphanization to Lead Structure Identification; Springer: Berlin/Heidelberg, Germany, 2006; Available online: https:/ /link.springer.com/ chapter/10.1007/2789_2006_007 (accessed on 28 September 2017).

62. Thompson, M.D.; Burnham, W.M.; Cole, D.E. The G protein-coupled receptors: Pharmacogenetics and disease. Crit. Rev. Clin. Lab. Sci. 2005, 42, 311-392. [CrossRef] [PubMed]

63. Feldman, H.J.; Hogue, C.W. A fast method to sample real protein conformational space. Proteins 2000, 39, 112-131. [CrossRef]

64. Galtier, N.; Gouy, M.; Gautier, C. SEAVIEW and PHYLO_WIN: Two graphic tools for sequence alignment and molecular phylogeny. Comput. Appl. Biosci. 1996, 12, 543-548. [CrossRef] [PubMed]

65. Bulenger, S.; Marullo, S.; Bouvier, M. Emerging role of homo- and heterodimerization in G-protein-coupled receptor biosynthesis and maturation. Trends Pharmacol. Sci. 2005, 26, 131-137. [CrossRef] [PubMed]

66. Xu, T.R.; Ward, R.J.; Pediani, J.D.; Milligan, G. The orexin $\mathrm{OX}_{1}$ receptor exists predominantly as a homodimer in the basal state: Potential regulation of receptor organization by both agonist and antagonist ligands. Biochem. J. 2011, 439, 171-183. [CrossRef] [PubMed]

67. Ward, R.J.; Pediani, J.D.; Milligan, G. Heteromultimerization of cannabinoid CB(1) receptor and orexin OX(1) receptor generates a unique complex in which both protomers are regulated by orexin A. J. Biol. Chem. 2011, 286, 37414-37428. [CrossRef] [PubMed]

68. Wang, C.; Pan, Y.; Zhang, R.; Bai, B.; Chen, J.; Randeva, H.S. Heterodimerization of mouse orexin type 2 receptor variants and the effects on signal transduction. Biochim. Biophys. Acta 2014, 1843, 652-663. [CrossRef] [PubMed]

69. Jantti, M.H.; Mandrika, I.; Kukkonen, J.P. Human orexin/hypocretin receptors form constitutive homo- and heteromeric complexes with each other and with human CB1 cannabinoid receptors. Biochem. Biophys. Res. Commun. 2014, 445, 486-490. [CrossRef] [PubMed]

70. Thompson, M.D.; Storm van's Gravesande, K.; Galczenski, H.; Burnham, W.M.; Siminovitch, K.A.; Zamel, N.; Slutsky, A.; Drazen, J.M.; George, S.R.; Evans, J.F.; et al. A cysteinyl leukotriene 2 receptor variant is associated with atopy in the population of Tristan da Cunha. Pharmacogenetics 2003, 13, 641-649. [CrossRef] [PubMed]

71. Thompson, M.D.; Capra, V.; Takasaki, J.; Maresca, G.; Rovati, G.E.; Slutsky, A.S.; Lilly, C.; Zamel, N.; McIntyre Burnham, W.; Cole, D.E.; et al. A functional G300S variant of the cysteinyl leukotriene 1 receptor is associated with atopy in a Tristan da Cunha isolate. Pharmacogenet. Genom. 2007, 17, 539-549. [CrossRef] [PubMed]

72. Thompson, M.D.; Takasaki, J.; Capra, V.; Rovati, G.E.; Siminovitch, K.A.; Burnham, W.M.; Hudson, T.J.; Bosse, Y.; Cole, D.E. G-protein-coupled receptors and asthma endophenotypes: The cysteinyl leukotriene system in perspective. Mol. Diagn. Ther. 2006, 10, 353-366. [CrossRef] [PubMed]

73. Capra, V.; Thompson, M.D.; Sala, A.; Cole, D.E.; Folco, G.; Rovati, G.E. Cysteinyl-leukotrienes and their receptors in asthma and other inflammatory diseases: Critical update and emerging trends. Med. Res. Rev. 2007, 27, 469-527. [CrossRef] [PubMed]

74. Thompson, M.D.; Capra, V.; Clunes, M.T.; Rovati, G.E.; Stankova, J.; Maj, M.C.; Duffy, D.L. Cysteinyl leukotrienes pathway genes, atopic asthma and drug response: From population isolates to large genome-wide association studies. Front Pharmacol. 2016, 7, 299. [CrossRef] [PubMed]

75. Zhang, S.; Blache, D.; Vercoe, P.E.; Adam, C.L.; Blackberry, M.A.; Findlay, P.A.; Eidne, K.A.; Martin, G.B. Expression of orexin receptors in the brain and peripheral tissues of the male sheep. Regul. Pept. 2005, 124, 81-87. [CrossRef] [PubMed]

76. Li, Y.; Chen, J.; Bai, B.; Du, H.; Liu, Y.; Liu, H. Heterodimerization of human apelin and kappa opioid receptors: Roles in signal transduction. Cell. Signal. 2012, 24, 991-1001. [CrossRef] [PubMed]

77. Chen, J.; Zhang, R.; Chen, X.; Wang, C.; Cai, X.; Liu, H.; Jiang, Y.; Liu, C.; Bai, B. Heterodimerization of human orexin receptor 1 and kappa opioid receptor promotes protein kinase A/cAMP-response element binding protein signalling via a Galphas-mediated mechanism. Cell. Signal. 2015, 27, 1426-1438. [CrossRef] [PubMed] 
78. Huang, H.; Acuna-Goycolea, C.; Li, Y.; Cheng, H.M.; Obrietan, K.; van den Pol, A.N. Cannabinoids excite hypothalamic melanin-concentrating hormone but inhibit hypocretin/orexin neurons: Implications for cannabinoid actions on food intake and cognitive arousal. J. Neurosci. 2007, 27, 4870-4881. [CrossRef] [PubMed]

79. Zheng, H.; Pearsall, E.A.; Hurst, D.P.; Zhang, Y.; Chu, J.; Zhou, Y.; Reggio, P.H.; Loh, H.H.; Law, P.Y. Palmitoylation and membrane cholesterol stabilize mu-opioid receptor homodimerization and $\mathrm{G}$ protein coupling. BMC Cell Biol. 2012, 13. [CrossRef] [PubMed]

80. Shang, Y.; Filizola, M. Opioid receptors: Structural and mechanistic insights into pharmacology and signalling. Eur. J. Pharmacol. 2015, 763, 206-213. [CrossRef] [PubMed]

81. Haj-Dahmane, S.; Shen, R.Y. The wake-promoting peptide orexin-B inhibits glutamatergic transmission to dorsal raphe nucleus serotonin neurons through retrograde endocannabinoid signalling. J. Neurosci. 2005, 25, 896-905. [CrossRef] [PubMed]

82. Turunen, P.M.; Jantti, M.H.; Kukkonen, J.P. OX1 orexin/hypocretin receptor signalling through arachidonic acid and endocannabinoid release. Mol. Pharmacol. 2012, 82, 156-167. [CrossRef] [PubMed]

83. Ho, Y.C.; Lee, H.J.; Tung, L.W.; Liao, Y.Y.; Fu, S.Y.; Teng, S.F.; Liao, H.T.; Mackie, K.; Chiou, L.C. Activation of orexin 1 receptors in the periaqueductal gray of male rats leads to antinociception via retrograde endocannabinoid (2-arachidonoylglycerol)-induced disinhibition. J. Neurosci. 2011, 31, 14600-14610. [CrossRef] [PubMed]

84. Wager-Miller, J.; Westenbroek, R.; Mackie, K. Dimerization of G protein-coupled receptors: CB1 cannabinoid receptors as an example. Chem. Phys. Lipids 2002, 121, 83-89. [CrossRef]

85. Kearn, C.S.; Blake-Palmer, K.; Daniel, E.; Mackie, K.; Glass, M. Concurrent stimulation of cannabinoid CB1 and dopamine D2 receptors enhances heterodimer formation: A mechanism for receptor cross-talk? Mol. Pharmacol. 2005, 67, 1697-1704. [CrossRef] [PubMed]

86. Hern, J.A.; Baig, A.H.; Mashanov, G.I.; Birdsall, B.; Corrie, J.E.; Lazareno, S.; Molloy, J.E.; Birdsall, N.J. Formation and dissociation of M1 muscarinic receptor dimers seen by total internal reflection fluorescence imaging of single molecules. Proc. Natl. Acad. Sci. USA 2010, 107, 2693-2698. [CrossRef] [PubMed]

87. Pin, J.P.; Kniazeff, J.; Liu, J.; Binet, V.; Goudet, C.; Rondard, P.; Prezeau, L. Allosteric functioning of dimeric class C G-protein-coupled receptors. FEBS J. 2005, 272, 2947-2955. [CrossRef] [PubMed]

88. Maurel, D.; Comps-Agrar, L.; Brock, C.; Rives, M.L.; Bourrier, E.; Ayoub, M.A.; Bazin, H.; Tinel, N.; Durroux, T.; Prezeau, L.; et al. Cell-surface protein-protein interaction analysis with time-resolved FRET and snap-tag technologies: Application to GPCR oligomerization. Nat. Methods 2008, 5, 561-567. [CrossRef] [PubMed]

89. Kilpatrick, L.E.; Hill, S.J. The use of fluorescence correlation spectroscopy to characterize the molecular mobility of fluorescently labelled G protein-coupled receptors. Biochem. Soc. Trans. 2016, 44, 624-629. [CrossRef] [PubMed]

90. Hague, C.; Uberti, M.A.; Chen, Z.; Hall, R.A.; Minneman, K.P. Cell surface expression of $\alpha_{1 D^{-a d r e n e r g i c ~}}$ receptors is controlled by heterodimerization with $\alpha_{1 \mathrm{~B}}$-adrenergic receptors. J. Biol. Chem. 2004, 279, 15541-15549. [CrossRef] [PubMed]

91. Prinster, S.C.; Holmqvist, T.G.; Hall, R.A. $\alpha_{2 C}$-adrenergic receptors exhibit enhanced surface expression and signalling upon association with $\beta_{2}$-adrenergic receptors. J. Pharmacol. Exp. Ther. 2006, 318, 974-981. [CrossRef] [PubMed]

92. Chen, J.; Randeva, H.S. Genomic organization of mouse orexin receptors: Characterization of two novel tissue-specific splice variants. Mol. Endocrinol. 2004, 18, 2790-2804. [CrossRef] [PubMed]

93. Cvejic, S.; Devi, L.A. Dimerization of the delta opioid receptor: Implication for a role in receptor internalization. J. Biol. Chem. 1997, 272, 26959-26964. [CrossRef] [PubMed]

94. Grant, M.; Patel, R.C.; Kumar, U. The role of subtype-specific ligand binding and the C-tail domain in dimer formation of human somatostatin receptors. J. Biol. Chem. 2004, 279, 38636-38643. [CrossRef] [PubMed]

95. Navarro, G.; Quiroz, C.; Moreno-Delgado, D.; Sierakowiak, A.; McDowell, K.; Moreno, E.; Rea, W.; Cai, N.S.; Aguinaga, D.; Howell, L.A.; et al. Orexin-corticotropin-releasing factor receptor heteromers in the ventral tegmental area as targets for cocaine. J. Neurosci. 2015, 35, 6639-6653. [CrossRef] [PubMed]

96. Scott, M.M.; Marcus, J.N.; Pettersen, A.; Birnbaum, S.G.; Mochizuki, T.; Scammell, T.E.; Nestler, E.J.; Elmquist, J.K.; Lutter, M. Hcrtr1 and 2 signalling differentially regulates depression-like behaviors. Behav. Brain Res. 2011, 222, 289-294. [CrossRef] [PubMed] 
97. Salomon, R.M.; Ripley, B.; Kennedy, J.S.; Johnson, B.; Schmidt, D.; Zeitzer, J.M.; Nishino, S.; Mignot, E. Diurnal variation of cerebrospinal fluid hypocretin-1 (Orexin-A) levels in control and depressed subjects. Biol. Psychiatry 2003, 54, 96-104. [CrossRef]

98. Nollet, M.; Gaillard, P.; Tanti, A.; Girault, V.; Belzung, C.; Leman, S. Neurogenesis-independent antidepressant-like effects on behavior and stress axis response of a dual orexin receptor antagonist in a rodent model of depression. Neuropsychopharmacology 2012, 37, 2210-2221. [CrossRef] [PubMed]

99. Rogala, B.; Li, Y.; Li, S.; Chen, X.; Kirouac, G.J. Effects of a post-shock injection of the kappa opioid receptor antagonist norbinaltorphimine (norBNI) on fear and anxiety in rats. PLoS ONE 2012, 7. [CrossRef] [PubMed]

100. Schwarzer, C. 30 years of dynorphins-new insights on their functions in neuropsychiatric diseases. Pharmacol. Ther. 2009, 123, 353-370. [CrossRef] [PubMed]

101. Robinson, J.D.; McDonald, P.H. The orexin 1 receptor modulates kappa opioid receptor function via a JNK-dependent mechanism. Cell. Signal. 2015, 27, 1449-1456. [CrossRef] [PubMed]

102. Baimel, C.; Lau, B.K.; Qiao, M.; Borgland, S.L. Projection-target-defined effects of orexin and dynorphin on VTA dopamine neurons. Cell Res. 2017, 18, 1346-1355. [CrossRef] [PubMed]

103. Bruchas, M.R.; Chavkin, C. Kinase cascades and ligand-directed signalling at the kappa opioid receptor. Psychopharmacology 2010, 210, 137-147. [CrossRef] [PubMed]

104. Nocjar, C.; Zhang, J.; Feng, P.; Panksepp, J. The social defeat animal model of depression shows diminished levels of orexin in mesocortical regions of the dopamine system, and of dynorphin and orexin in the hypothalamus. Neuroscience 2012, 218, 138-153. [CrossRef] [PubMed]

105. Rios, C.; Gomes, I.; Devi, L.A. Mu opioid and CB1 cannabinoid receptor interactions: Reciprocal inhibition of receptor signalling and neuritogenesis. Br. J. Pharmacol. 2006, 148, 387-395. [CrossRef] [PubMed]

106. Carriba, P.; Ortiz, O.; Patkar, K.; Justinova, Z.; Stroik, J.; Themann, A.; Muller, C.; Woods, A.S.; Hope, B.T.; Ciruela, F.; et al. Striatal adenosine A2A and cannabinoid CB1 receptors form functional heteromeric complexes that mediate the motor effects of cannabinoids. Neuropsychopharmacology 2007, 32, 2249-2259. [CrossRef] [PubMed]

107. Rozenfeld, R.; Gupta, A.; Gagnidze, K.; Lim, M.P.; Gomes, I.; Lee-Ramos, D.; Nieto, N.; Devi, L.A. AT1R-CB 1 R heteromerization reveals a new mechanism for the pathogenic properties of angiotensin II. EMBO J. 2011, 30, 2350-2363. [CrossRef] [PubMed]

108. Kano, M.; Ohno-Shosaku, T.; Hashimotodani, Y.; Uchigashima, M.; Watanabe, M. Endocannabinoid-mediated control of synaptic transmission. Physiol. Rev. 2009, 89, 309-380. [CrossRef] [PubMed]

109. Ellis, J.; Pediani, J.D.; Canals, M.; Milasta, S.; Milligan, G. Orexin-1 receptor-cannabinoid CB1 receptor heterodimerization results in both ligand-dependent and -independent coordinated alterations of receptor localization and function. J. Biol. Chem. 2006, 281, 38812-38824. [CrossRef] [PubMed]

110. Zhang, Y.; Gilliam, A.; Maitra, R.; Damaj, M.I.; Tajuba, J.M.; Seltzman, H.H.; Thomas, B.F. Synthesis and biological evaluation of bivalent ligands for the cannabinoid 1 receptor. J. Med. Chem. 2010, 53, 7048-7060. [CrossRef] [PubMed]

111. Le Naour, M.; Akgun, E.; Yekkirala, A.; Lunzer, M.M.; Powers, M.D.; Kalyuzhny, A.E.; Portoghese, P.S. Bivalent ligands that target mu opioid (MOP) and cannabinoid1 (CB1) receptors are potent analgesics devoid of tolerance. J. Med. Chem. 2013, 56, 5505-5513. [CrossRef] [PubMed]

112. Zhu, F.; Wang, X.Q.; Chen, Y.N.; Yang, N.; Lang, S.Y.; Zuo, P.P.; Zhang, J.T.; Li, R.S. Changes and overlapping distribution in the expression of CB1/OX1-GPCRs in rat hippocampus by kainic acid-induced status epilepticus. Brain Res. 2015, 1597, 14-27. [CrossRef] [PubMed]

113. Deshpande, L.S.; DeLorenzo, R.J. Acetaminophen inhibits status epilepticus in cultured hippocampal neurons. Neuroreport 2011, 22, 15-18. [CrossRef] [PubMed]

114. Pugin, D.; Foreman, B.; De Marchis, G.M.; Fernandez, A.; Schmidt, J.M.; Czeisler, B.M.; Mayer, S.A.; Agarwal, S.; Lesch, C.; Lantigua, H.; et al. Is pentobarbital safe and efficacious in the treatment of super-refractory status epilepticus: A cohort study. Crit. Care 2014, 18, R103. [CrossRef] [PubMed]

115. Kogan, N.M.; Mechoulam, R. Cannabinoids in health and disease. Dialogues Clin. Neurosci. 2007, 9, 413-430. [PubMed]

116. Maejima, T.; Ohno-Shosaku, T.; Kano, M. Endogenous cannabinoid as a retrograde messenger from depolarized postsynaptic neurons to presynaptic terminals. Neurosci. Res. 2001, 40, 205-210. [CrossRef] 
117. Ludanyi, A.; Eross, L.; Czirjak, S.; Vajda, J.; Halasz, P.; Watanabe, M.; Palkovits, M.; Magloczky, Z.; Freund, T.F.; Katona, I. Downregulation of the CB1 cannabinoid receptor and related molecular elements of the endocannabinoid system in epileptic human hippocampus. J. Neurosci. 2008, 28, 2976-2990. [CrossRef] [PubMed]

118. Falenski, K.W.; Carter, D.S.; Harrison, A.J.; Martin, B.R.; Blair, R.E.; DeLorenzo, R.J. Temporal characterization of changes in hippocampal cannabinoid $\mathrm{CB}_{1}$ receptor expression following pilocarpine-induced status epilepticus. Brain Res. 2009, 1262, 64-72. [CrossRef] [PubMed]

119. Bojnik, E.; Turunc, E.; Armagan, G.; Kanit, L.; Benyhe, S.; Yalcin, A.; Borsodi, A. Changes in the cannabinoid (CB1) receptor expression level and G-protein activation in kainic acid induced seizures. Epilepsy Res. 2012, 99, 64-68. [CrossRef] [PubMed]

120. Khaspekov, L.G.; Brenz Verca, M.S.; Frumkina, L.E.; Hermann, H.; Marsicano, G.; Lutz, B. Involvement of brain-derived neurotrophic factor in cannabinoid receptor-dependent protection against excitotoxicity. Eur. J. Neurosci. 2004, 19, 1691-1698. [CrossRef] [PubMed]

121. Cristino, L.; Busetto, G.; Imperatore, R.; Ferrandino, I.; Palomba, L.; Silvestri, C.; Petrosino, S.; Orlando, P.; Bentivoglio, M.; Mackie, K.; et al. Obesity-driven synaptic remodeling affects endocannabinoid control of orexinergic neurons. Proc. Natl. Acad. Sci. USA 2013, 110, E2229-2238. [CrossRef] [PubMed]

122. Doreulee, N.; Alania, M.; Vashalomidze, G.; Skhirtladze, E.; Kapanadze, T. Orexinergic system and pathophysiology of epilepsy. Georgian Med. News 2010, 188, 74-79.

(C) 2017 by the authors. Licensee MDPI, Basel, Switzerland. This article is an open access article distributed under the terms and conditions of the Creative Commons Attribution (CC BY) license (http://creativecommons.org/licenses/by/4.0/). 